\title{
Pieczęcie z zasobu Archiwum Państwowego w Lublinie, Oddział w Radzyniu Podlaskim - na marginesie kwerend archiwalnych
}

АвsтrAкт: W artykule przedstawiono odciski pieczęci z XVI, XVII, XVIII i początku XIX w., które znajdują się w zasobie Archiwum Państwowego w Lublinie Oddział w Radzyniu Podlaskim. Omówione przykłady to pieczęć miejska oraz pieczęcie osobiste duchownych, biskupów i proboszczów, starostów mielnickich, pieczęcie sygnetowe magnatów i szlachty, w tym właścicieli majątków ziemskich w Międzyrzecu Podlaskim, Radzyniu Podlaskim, Dobratyczach.

sŁowa KLuczowe: sfragistyka, Archiwum Państwowe w Lublinie Oddział w Radzyniu Podlaskim, starostwo mielnickie, ziemia łukowska, dobra ziemskie, województwo podlaskie, województwo lubelskie, diecezja łucka, diecezja włodzimiersko-brzeska

ABSTRACT: The article presents the imprints of seals from the $16^{\text {th }}, 17^{\text {th }}, 18^{\text {th }}$ and early $19^{\text {th }}$ century, which are stored in the collection of the State Archives in Lublin, Branch in Radzyń Podlaski. The presented examples comprise city seals and personal seals of clergymen, bishops and parish priests, Mielnik starosts, signet rings of noblemen and the gentry, including the owners of landed estates in Międzyrzec Podlaski, Radzyń Podlaski, Dobratycze.

KEYwORDs: sigillography (sphragistics), State Archives in Lublin Branch in Radzyń Podlaski, Mielnik starosty, Łuków region, landed estates, Podlasie province 
Zainteresowanie sfragistyką w ostatnich latach można zaobserwować również na płaszczyźnie badań archiwalnych. Studia nad pieczęcią dały początek działaniom nad przygotowaniem nowych metod opracowania materiałów sfragistycznych $\mathrm{w}$ archiwach państwowych, $\mathrm{w}$ tym nad ich opisem ${ }^{1}$. Istotnym zagadnieniem w pracy nad wskazówkami było doprecyzowanie definicji pieczęci. Dzięki temu wskazano, co powinno być traktowane jako pieczęć, a w konsekwencji, co powinno być jako pieczęć inwentaryzowane.

Marian Haisig w podręczniku sfragistyki zdefiniował pieczęć jako:

\section{(...) znak rozpoznawczo-własnościowy określonej osoby fizycznej lub prawnej, wyciśnięty za pomocą twardego stempla w odpowiedniej masie plastycznej lub farbie, a pełniący rolę świadectwa wiarygodności i mocy prawnej, wykładnika jego właściciela, jak również środka kontrolującego i zabezpieczającego nienaruszalność zamkniętego pisma lub przedmiotu².}

To jedna $\mathrm{z}$ wielu definicji pieczęci. Ich przeglądu dokonał M. Hlebionek w artykule Pieczęć jako obiekt archiwalny ${ }^{3}$. Podsumowując analizę pojęć, dostępnych zarówno na gruncie polskim, jak i zagranicznym, zauważył, że definicje pieczęci używane w sfragistyce nie są wystarczające z punktu widzenia archiwistyki. W niewielkim stopniu zwracają bowiem uwagę na przemiany, które zachodziły $\mathrm{w}$ formie i funkcjonowaniu pieczęci w późniejszych niż średniowiecze epokach. Z płaszczyzny archiwistyki jest to o tyle istotne, że zdecydowaną większość zasobu sfragistycznego w archiwach państwowych stanowią pieczęcie nowożytne $e^{4}$. Ponadto obok odcisków uwierzytelniających w zasobach archiwów znaleźć można

${ }^{1}$ W 2020 r. ukazały się drukiem wyniki prac zespołu naukowego powołanego przez Naczelnego Dyrektora Archiwów Państwowych w 2008 r. do przygotowania wskazówek metodycznych do opracowania materiałów sfragistycznych w zasobie archiwów państwowych. W publikacji zebrano podstawowe wiadomości z zakresu nauki o pieczęciach, w tym ich budowy, typologii, aspektów prawnych funkcjonowania, znaczenia zabytków sfragistycznych jako nośników informacji i konserwacji, przedstawiono również projekt wskazówek metodycznych do opracowania materiałów sfragistycznych. Zagadnienia z zakresu metodyki opracowania archiwalnego pieczęci przybliżyła Jagoda Jankowska. Zob.: Opracowanie materiałów sfragistycznych $w$ archiwach, red. P. Gut, M. Hlebionek, Warszawa 2020, ss. 219.

${ }^{2}$ M. Haisig, Sfragistyka ogólna, [w:] M. Gumowski, M. Haisig, S. Mikucki, Sfragistyka, Warszawa 1960, s. 59.

${ }^{3}$ M. Hlebionek, Pieczęć jako obiekt archiwalny, [w:] Toruńskie Konfrontacje Archiwalne, t. 2, red. W. Chorążyczewski, A. Rosa, Toruń 2011, s. 303-320.

${ }^{4}$ Idem, Pieczęć jako obiekt archiwalny. Wybrane problemy, s. 2, cyt. za Naukowy Portal Archiwalny < ArchNet, http://www.adacta.archiwa.net/file/2010/hleb_piecz.pdf>, [dostęp 20.11.2020]. 
wiele pieczęci stosowanych w pracy kancelaryjnej, tj. nagłówkowych, imiennych, pieczęci wpływu.

Według M. Hlebionka pojęcie „pieczęci powinno podkreślać dwoistość jego rozumienia: szerokiego (każdy mechanicznie powielony za pomocą stempla napis bądź wyobrażenie) i węższego (ograniczonego do odcisków pełniących określone funkcje, które wskazywała będzie definicja pieczęci, wśród których pierwszoplanowa powinna być funkcja uwierzytelniająca)" ${ }^{\text {"5 }}$. W węższym znaczeniu za pieczęć proponuje uznać „powtarzalny znak uwierzytelniający dokument w miejsce podpisu bądź obok niego, mogący służyć także do fizycznego zabezpieczania nienaruszalności rzeczy lub pism, albo jako wykładnia woli dysponenta. Znak ten zazwyczaj jest powielany przez odciśnięcie matrycy [tłok, typariusz] w plastycznej masie bądź też w barwniku [odcisk]". W szerszym rozumieniu natomiast proponuje przyjąć: „każdy mechanicznie powielony za pomocą stempla [tłoka, typariusza] napis bądź wyobrażenie"6.

Definicja pieczęci dopracowana przez autorów wskazówek metodycznych kładzie nacisk na funkcje pieczęci. Pozwala to wykluczyć spośród materiałów sfragistycznych dużą grupę obiektów, które pieczęciami nie są, stosowane w pracy biurowej służyły powieleniu sformalizowanych treści dokumentu. Pieczęcie nagłówkowe, wpływu, imienne oraz inne (parasigilla) nie znajdują się w kręgu zainteresowania sfragistyki, ale raczej aktoznawstwa ${ }^{7}$. Z metodycznego punktu widzenia podział obiektów na dwie grupy, tj. pieczęcie (właściwe) i parasigilla, ma istotne konsekwencje, ogranicza bowiem zbiór, który ma być przedmiotem archiwalnego opracowania ${ }^{8}$.

$\mathrm{W}$ archiwalnym opisie materiałów sfragistycznych znalazły się informacje dotyczące twórcy pieczęci, jej kształtu, wymiarów. Do istotnych należy zaliczyć opis wizerunku, treść legendy, okres powstania stempla9. W ostatnich latach przygotowano również materiały do polskiego słownika sfragistycznego. Mają one posłużyć jako pomoc dla archiwistów, którzy zajmują się opracowaniem

${ }^{5}$ Ibidem, s. 6.

${ }^{6}$ Ibidem.

${ }^{7}$ M. Hlebionek, Sfragistyka w systemie nauk. Podstawowe pojęcia sfragistyczne, [w:] Opracowanie materiałów sfragistycznych, s. 19; P. Gut, M. Hlebionek, Prawo pieczętne: rodzaje kancelaryjno-prawne ifałszerstwa pieczęci. Księgi funkcjonowania pieczęci, [w:] Opracowanie materiałów sfragistycznych, s. 34 .

${ }^{8}$ J. Jankowska, Metodyka opracowania archiwalnego pieczęci, [w:] Opracowanie materiałów sfragistycznych, s. 67 .

${ }^{9}$ Wskazówki metodyczne do opracowania materiałów sfragistycznych $w$ zasobie archiwów państwowych, [w:] Opracowanie materiałów sfragistycznych, s. 97-219. 
materiałów sfragistycznych. Znajdują się w nich definicje pojęć z dziedzin sfragistyki oraz propozycje klasyfikacji pieczęci, ich elementów, dysponentów. Jest to pierwsza polska publikacja, która próbuje zebrać w jednym miejscu definicje pojęć $\mathrm{z}$ różnych działów sfragistyki ${ }^{10}$. W wielu opracowaniach dotyczących perspektyw badań sfragistycznych zauważono, że ich rozwój uzależniony jest od stopnia zinwentaryzowania obiektów przechowywanych w archiwach, bibliotekach i muze$\mathrm{ach}^{11}$. Postulat powyższy pomimo upływu lat nadal pozostaje aktualny. Tym bardziej ważne są prace przybliżające przechowywane w archiwach pieczęcie ${ }^{12}$.

Materiały archiwalne znajdujące się w zasobie Archiwum Państwowego w Lublinie Oddział w Radzyniu Podlaskim to przede wszystkim akta proweniencji dziewiętnasto- i dwudziestowiecznej. Wśród nich można jednak odnaleźć dokumenty starsze, interesujące jako źródło historyczne, zwłaszcza do badań historii

${ }^{10}$ Materialy do polskiego słownika sfragistycznego, oprac. A. Baniecki i in., „Archiwista Polski” 59, $\mathrm{nr}$ 3, 2010, s. 43-56; Vocabularium internationale sigillographicum, red. K. Müller, L. Vrtel, M. Hlebionek, V. Keresztes, tłum. na j. pol. B. Jusypenko, oprac. M. Hlebionek, A. Baniecki, D. Bednarek, R. Forysiak-Wójciński, J. Grabowski, P. Gut, P. Pokora, D. Żygadło, Bratislava 2016, ss. 608 .

${ }^{11} \mathrm{Na}$ gruncie polskim pierwszym krokiem w kierunku zwiększenia dostępności do źródeł, a co za tym idzie również rozwoju badań sfragistycznych, było pismo Naczelnego Dyrektora Archiwów Państwowych z 22 maja 1961 r. w sprawie inwentaryzacji pieczęci oraz zarządzenie nr 8, które wprowadziło wytyczne do opracowania zbiorów pieczęci przechowywanych $\mathrm{w}$ archiwach państwowych. Odpowiadając na postulaty Mariana Haisiga powyższym dokumentem, Naczelna Dyrekcja Archiwów Państwowych podjęła akcję inwentaryzacji pieczęci w archiwach, z jednoczesnym ustaleniem jej zasad. Zob. Zbiór przepisów archiwalnych wydanych przez Naczelnego Dyrektora Archiwów Państwowych w latach 1952-2000, oprac. M. Tarakanowska, E. Rosowska, Warszawa 2001, s. 301-310.

12 Zob. M. Haisig, Osiagnięcia i postulaty w zakresie sfragistyki polskiej, „Studia Źródłoznawcze”, t. 4, 1959, s. 164; K. Chojnacka, Międzyarchiwalny katalog materiałów sfragistycznych, „Archeion” t. 73, 1982, s. 101-110; D. Bednarek, D. Sokołowska, D. Żygadło, Problem opisu pieczęci (w formacie FOPAR na podstawie kart inwentarzowych pieczęci A i B), [w:] Komputeryzacja Archiwów, t. 1, Problemy opracowania archiwaliów staropolskich w skomputeryzowanych systemach informacyjnych, red. B. Ryszewski, Toruń 1994, s. 29 i in.; Z. Piech, Perspektywy polskich badań sfragistycznych, [w:] Pieczęcie w dawnej Rzeczypospolitej. Stan i perspektywy badań, red. Z. Piech, J. Pakulski, J. Wroniszewski, Warszawa 2006, s. 36, 42; M. Hlebionek, W stronę SIGILLUM. Problemy archiwalnego opisu pieczęci, „Archiwista Polski”, nr 4, 2006, s. 19-26; idem, Problemy opisu materiałów sfragistycznych w polskich archiwach, Сфргістичний щорічник, Вип. I, 2011, s. 222-251; idem, Standardy międzynarodowe w archiwalnym opisie materiałów sfragistycznych. Przykład francuski i włoski, [w:] Toruńskie Konfrontacje Archiwalne, t. 3, red. W. Chorążyczewski, A. Rosa, Toruń 2012, s. 219-249; idem, Kilka uwag o pieczęciach w XIX w. na przykładzie zaboru pruskiego, [w:] Nauki pomocnicze historii. Teoria, metody badań, dydaktyka, red. A. Jaworska, R. Jop, Warszawa 2013, s. 191-200. 
lokalnej, ale także pod względem formy. $Z$ uwagi na rodzaj i rangę - w dużej mierze są to przywileje, ich odpisy, a także pełnomocnictwa - dokumenty opatrzone są pieczęciami wystawców.

Podobnie jak aktotwórcy, tak i dysponenci pieczęci, których odciski zachowały się na dokumentach, pochodzą przede wszystkim z XIX i XX w. W artykule przedstawiono wybrane odciski pieczęci z XVI-XVIII i początku XIX w. Ponieważ tekst to wynik badań sondażowych, nie należy go traktować jako pełny katalog pieczęci z zasobu Oddziału w Radzyniu Podlaskim, ale przyczynek do dalszych prac nad nimi, w tym związanych z ich inwentaryzacją. Opisane obiekty odnaleziono podczas kwerend archiwalnych $w$ trakcie opracowania akt oraz poprawy ich ewidencji ${ }^{13}$. Materiały sfragistyczne pochodzą z zespołów akt hipotecznych i notarialnych. To najstarsze pod względem twórcy materiały archiwalne.

$\mathrm{Na}$ omówioną w niniejszym tekście najstarszą część zasobu sfragistycznego Oddziału w Radzyniu Podlaskim składają się odciski pieczęci przy dokumentach i aktach. $Z$ uwagi na ilość i rozproszenie są słabo rozpoznane i nie były inwentaryzowane. Na podstawie wstępnej kwerendy należy stwierdzić, że reprezentują różne grupy dysponentów.

Zgodnie z typologią pieczęci według dysponenta zaproponowaną w Materiałach do polskiego słownika sfragistycznego ${ }^{14}$ obiekty przechowywane w Oddziale w Radzyniu Podlaskim to pieczęcie świeckie, w tym miejska i osób fizycznych oraz kościelne, a wśród nich pieczęcie duchowieństwa (biskupów i niższego duchowieństwa - proboszczów). Większość odnalezionych odcisków to pieczęcie osobiste. Należy je rozumieć jako wszystkie pieczęcie z elementami pozwalającymi na identyfikację osoby fizycznej, która się nimi posługiwała. Umożliwia to umieszczona inskrypcja oraz elementy graficzne, przede wszystkim herb. Do pieczęci osobistych należy zaliczyć imienne pieczęcie biskupów, urzędników świeckich oraz pieczecie sygnetowe.

Oprócz podziału ze względu na osobę dysponenta, klasyfikację pieczęci można dokonać również ze względów prawnoformalnych na dwie grupy - pieczęcie urzędnicze oraz pieczęcie prywatne używane przez właściciela bez względu na pełnioną funkcję publiczną. Pieczęciami prywatnymi są pieczęcie sygnetowe. Pieczęcie urzędnicze, oprócz prezentowania herbu dysponenta, w legendzie podają

${ }^{13} \mathrm{~W} 2013$ r. przeprowadzono wstępną kwerendę, która miała na celu rozpoznanie zasobu sfragistycznego Oddziału. Efektem prac była wystawa pt. „Historia Radzynia w autograf i pieczęć wpisana”, Radzyń Podlaski 2013.

${ }^{14}$ Materiały do polskiego słownika sfragistycznego, s. 46-47. 
piastowane godności. Pieczęciami tymi uwierzytelniano dokumenty, które były wynikiem sprawowanych czynności urzędniczych ${ }^{15}$. Ostatnim przykładem omawianego odcisku jest pieczęć miejska. W jej legendzie określono nazwę ośrodka, który miał prawo posługiwać się tłokiem.

Odciski przechowywane w Oddziale w Radzyniu podzielić można nie tylko na grupy według dysponentów pieczęci, ale także z uwagi na materiał, z jakiego były wykonane, oraz sposób związania z dokumentem. Wśród obiektów z XVI, XVII i XVIII w. natrafiono na pieczęcie woskowe wiszące (odnaleziono jedną taką pieczęć) oraz woskowe i lakowe wyciśnięte na dokumencie, przez papier lub opłatek, na podkładzie z wosku lub laku.

Najstarszym odnalezionym w zasobie radzyńskiego archiwum dokumentem uwierzytelnionym pieczęcią jest przywilej dla kościoła w Rossoszy wydany w Janowie 10 II 1600 r. przez biskupa łuckiego Bernarda Maciejowskiego, późniejszego kardynała i prymasa Polski. Bernard Maciejowski herbu Ciołek (1548-1608), s. Bernarda i Elżbiety z Kamienieckich, biskup, kardynał, godność biskupa łuckiego sprawował w latach 1587-1600. Nauki pobierał w kolegium jezuickim w Wiedniu. Po powrocie do kraju przebywał na dworze Zygmunta II Augusta, a następnie Henryka Walezego. Od 1570 chorąży nadworny koronny. Był współpracownikiem kardynała Stanisława Hozjusza. Brał udział w wyprawach Stefana Batorego na Moskwę (1579-1581), za co otrzymał od króla starostwo borysławskie. Za sprawą

${ }^{15}$ Dyskusja nad rozgraniczeniem pieczęci urzędowych i urzędniczych toczyła się na kanwie badań nad pieczęciami starostów grodzkich. Marcin Hlebionek dzieli pieczęcie osobiste na urzędnicze i prywatne. Zaznacza, że granica pomiędzy nimi jest płynna, tym bardziej że w praktyce bardzo często pieczęcią prywatną opatrywano pisma urzędnicze, a dokumenty prywatne - urzędniczą. Mianem pieczęci urzędowych proponuje określić pieczęcie, które w legendzie wymieniają nazwę instytucji, w ikonografii zaś odwołują się do znaków im właściwych, a więc np. herbu państwowego lub herbu urzędującego starosty. Rozróżnienie uzależnia więc od depersonalizacji wizerunku pieczęci. Pieczęcie, które prezentują znak dysponenta, a w legendzie wymieniają piastowane przezeń godności i służą do uwierzytelnienia dokumentów powstałych w wyniku sprawowania określonej godności, nazywa „pieczęciami urzędniczymi”. Do takiego wyjaśnienia przychyla się również Karol Nabiałek. Inną klasyfikację pieczęci urzędników proponują Janusz Łosowski oraz Marek Adamczewski. Według nich pieczęcie urzędników należą do pieczęci urzędowych. Zob. J. Łosowski, Pieczęcie starostów chetmskich od drugiej połowy XVI do XVIII wieku, [w:] Pieczęć w Polsce średniowiecznej i nowożytnej. Zbiór studiów, Lublin 1998, s. 153-154; M. Adamczewski, Pieczęcie urzędowe władz lokalnych z obszaru Polski centralnej, cz. 2, Pieczęcie sądów szlacheckich do 1793 roku, Łódź 2010, s. 13; M. Hlebionek, O pieczęciach starosty generalnego Wielkopolski Adama Sędziwoja Czarnkowskiego, „Archiwa - Kancelarie - Zbiory”, t. 2, 2011, s. 12-13; K. Nabiałek, Pieczęcie starostów księstw oświęcimskiego i zatorskiego do 1563 roku, „Roczniki Historyczne” 85, 2019, s. 112-113. 
kard. Hozjusza, Piotra Skargi i Antonia Possevina wybrał stan duchowny. Studiował w Italii: prawo kanoniczne w Perugii, a teologię w Rzymie. Odegrał znaczącą rolę $\mathrm{w}$ przygotowaniu unii brzeskiej. W maju $1600 \mathrm{r}$. otrzymał nominację na biskupstwo krakowskie, które uroczyście objął w sierpniu 1600 r. Kolejne godności, które otrzymał, to: kardynał, arcybiskup gnieźnieński i Prymas Polski. Zmarł w 1608 r. Pochowany został w katedrze na Wawelu ${ }^{16}$.

Pieczęć Bernarda Maciejowskiego, biskupa łuckiego, jest okrągła (Kat. nr 1). Niestety legenda i pole pieczęci są nieczytelne. W polu pieczęci musiała znajdować się tarcza herbowa $z$ herbem Ciołek Maciejowskiego. Widoczny zarys na pieczęci świadczyć może o tym, że tarcza herbowa zwieńczona była infułą ${ }^{17}$.

Kolejny odcisk pieczęci, który zaliczyć możemy do grupy pieczęci dostojników kościelnych, znajduje się na odpisie dokumentu fundacyjnego kościoła szpitalnego w Międzyrzecu. Dokument fundacyjny wystawił w 1617 r. ówczesny właściciel dóbr międzyrzeckich Gabriel Tęczyński ${ }^{18}$. Odpis został potwierdzony przez Franciszka Antoniego Kobielskiego, biskupa łuckiego i brzeskiego w latach $1739-1755^{19}$ (Kat. nr 2).

W zasobie radzyńskiego archiwum znajduje się jeszcze jeden odcisk pieczęci biskupa Franciszka Antoniego Kobielskiego (Kat. nr 3). Pieczęć odnaleziono na dokumencie dotyczącym kolegiaty i parafii w Janowie z 1749 r., który dołączono do księgi hipotecznej dóbr Witulin. Dokument stanowi odpis z ksiąg mielnickich ${ }^{20}$.

Odciski pieczętne potwierdzające wolę depozytariuszy znajdują się na dwóch aktach fundacyjnych parafii i kościoła wyznania rzymskokatolickiego w Ostrówkach. Starszy z nich to przywilej z 1659 r., wystawiony przez marszałka nadwornego

16 A. Dicianówna, Kardynał Bernard Maciejowski jako opiekun uczonych i literatów, „Collectanea Theologica", t. 15, 1934, s. 323-359.

${ }^{17}$ Archiwum Państwowe w Lublinie Oddział w Radzyniu Podlaskim (dalej: APL OR), Hipoteka w Białej Podlaskiej (dalej: HB), poz. 204, Dokumenty do księgi hipotecznej Dobra ziemskie Korczówka.

18 A. Wędzki, Problem genezy Międzyrzeca Podlaskiego na tle procesów urbanizacyjnych na południowo-zachodnim pograniczu Podlasia, „Rocznik Międzyrzecki”, t. 6, 1974, s. 34-46.

19 Franciszek Antoni Kobielski herbu Poraj (1679-1755), s. Mikołaja Stanisława i Teresy Tarnowskiej herbu Jelita. Edukację pobierał u pijarów. Przeznaczony do kariery duchownej, znajdował się pod opieką krewnego, biskupa Stanisława Szembeka. Kanclerz królowej Marii Józefy. Wyświęcony w 1706, był kanonikiem łowickim, gnieźnieńskim i włocławskim, prepozytem krakowskim, dziekanem warszawskim. W 1725 został sufraganem kujawskim (biskup tytularny Antaeopolis), W 1736 prekonizowany na biskupstwo kamienieckie. Biskup łucki i brzeski od 1739 r. do śmierci w 1755 r. Został pochowany w Janowie Podlaskim. Zob. W. Szczygielski, Kobielski Franciszek Antoni herbu Poraj (1679-1755), [w:] Polski słownik biograficzny (dalej: PSB), t. 13, 1967-1968, s. 146-148.

${ }^{20}$ Ibidem, HB, poz. 754, s. 606. 
koronnego Łukasza Opalińskiego herbu Łodzia (1612-1662), który wraz z żoną Izabellą z Tęczyńskich uposażył nową parafię w dobrach międzyrzeckich. Dokument podpisali oboje małżonkowie, dodatkowym uwierzytelnieniem stała się również pieczęć Opalińskiego ${ }^{21}$ (Kat. nr 13).

Kolejny dokument dotyczący świątyni i parafii pw. św. Stanisława w Ostrówkach, to odpis przywileju, który wystawiła Elżbieta z Lubomirskich Sieniawska (1669/1670-1729). W $1718 \mathrm{r}$. przywilejem zabezpieczyła stały dochód na poczet remontu kościoła. Odpis przywileju został sporządzony i opieczętowany stemplem biskupa Józefa Olszańskiego, administratora diecezji łuckiej, prawdopodobnie w momencie remontu świątyni, który zakończył się przed $1737 \mathrm{rr}^{22}$ Inicjatorem remontu był ks. Andrzej Woszczarski, wymieniony w dokumencie. Pieczęć znajduje się w księdze hipotecznej dóbr ziemskich Międzyrzec Miasto ${ }^{23}$ (Kat. nr 4).

W zbiorze dokumentów do wspomnianej księgi hipotecznej znajduje się szereg odcisków stempli osób duchownych, w tym z XVIII i XIX w. ${ }^{24}$. Przykładem odcisku stempla duchownego kościoła greckokatolickiego jest pieczęć Teofila Godebskiego uwieczniona na dokumencie z 12 sierpnia 1746 r. (Kat. nr 5). Dokument dotyczy wyklęcia parafian cerkwi dołżańskiej za to, że nie wywiązywali się z dziesięciny ${ }^{25}$. Teofil Godebski herbu Godziemba występuje tu jako biskup włodzimierski i brzeski ${ }^{26}$.

Stan zachowania obiektu jest dobry, jednak z uwagi na głębokie wszycie dokumentu oraz częściowe umieszczenie pieczęci na tekście nie jest widoczny w całości. $\mathrm{Z}$ tego też powodu trudny do odczytania jest tekst legendy, którą stanowi imię i nazwisko dysponenta oraz określenie jego funkcji. Podpowiedź co do treści

\footnotetext{
${ }^{21}$ Ibidem, HR, sygn. 134, s. 92.

22 Józef Olszański, (zm. 1736/1738), sufragan chełmski (od 1727 r.). Syn Mikołaja Baltazara, rotmistrza królewskiego i Teresy z Wielhorskich, kasztelanki wołyńskiej herbu Kierdej. Pełnił obowiązki proboszcza w Łucku. 25 czerwca 1727 r. został mianowany biskupem tytularnym Serra i sufraganem chełmskim. Sakrę biskupią przyjął w 1728 r. Kanonik gnieźnieński (1730-1732), proboszcz, administrator diecezji łuckiej, infułat ołycki. Zmarł w Łucku i tam został pochowany. Zob. P. Mazur, Poczet biskupów chełmskich obrzadku łacińskiego, Chełm 2012, s. 46; S. Tylus, W sprawie datacji śmierci niektórych biskupów kresowych, „Archiwa, Biblioteki i Muzea Kościelne”, t. 70,1998 , s. 359 .

${ }^{23}$ HR, sygn. 134, s. 183.

${ }^{24}$ Ibidem.

${ }^{25}$ Ibidem, s. 133 .

${ }^{26}$ Teofil Godebski herbu Godziemba (zm. 1756 r.) - duchowny greckokatolicki, bazylianin. W 1720 ordynariusz pińsko-turowski, od 1730 r. biskup włodzimiersko-brzeski. Zob. D. Wereda, Biskupi unickiej diecezji włodzimiersko-brzeskiej w XVIII wieku, „Szkice Podlaskie”, t. 9, 2001, s. $61-75$.
} 
legendy przynosi fragment z formularza dokumentu: „Theofil na Godziembie Godebski z Bożej i Stolicy Stej Apostolskiej Łaski (...) Metropoliej Kijowskiej i Całey Rusi Biskup Włodzimirski i Brzeski”27.

W księdze dóbr międzyrzeckich, na odpisie przywileju fundacyjnego kościoła św. Mikołaja w Międzyrzecu odciśnięto pieczęć ówczesnego administratora diecezji łuckiej, proboszcza bialskiego, Tomasza de Stuart Haliburtona (zm. 3 VIII 1813 r. $)^{28}$. Fundatorem świątyni był Jan Nassutowicz, starosta brzeski, właściciel Międzyrzeca w XV w. Dokument fundacyjny wystawiony został w 1477 r. Odpis wykonano 15 II 1799 r. na podstawie dokumentu złożonego w archiwum janowskim (Kat. nr 6).

Do odcisków pieczętnych duchownych związanych z dobrami międzyrzeckimi zaliczyć należy również pieczęcie herbowe mniejsze, sygnetowe. Na dokumentach, które dołączono do księgi hipotecznej dóbr międzyrzeckich, znajduje się wiele odcisków pieczęci, w niniejszym tekście prezentowane są dwie.

Pierwsza z nich to pieczęć ks. Adama Kukiela, proboszcza parafii pw. św. Mikołaja w Międzyrzecu od 1802 r. $^{29}$ (Kat. nr 7). A. Kukiel (zm. 1831 r.) był księdzem, ale i uczonym, matematykiem, fizykiem i geografem, uczestnikiem obiadów czwartkowych u króla Stanisława Augusta Poniatowskiego. Z Międzyrzecem związany był przez blisko 30 lat. Własnym kosztem utrzymywał szkołę parafialną, a dzięki funduszom księcia Adama Czartoryskiego prowadził budowę nowej fasady świątyni $^{30}$. Kolejną pieczęcią sygnetową posługiwał się ks. Daniel Śnitko - paroch parafii w Dołdze ${ }^{31}$ (Kat. nr 8).

W grupie prezentowanych pieczęci kościelnych znajdują się pieczęcie biskupów, administratorów diecezji oraz duchownych niższych rangą - proboszczów. Wielkość odcisków uzależniona jest od miejsca, które zajmował jej dysponent w hierarchii kościelnej. Wymiary prezentowanych w katalogu odcisków pieczęci biskupów mają od $55 \mathrm{~mm}$ do $45 \mathrm{~mm}$. Odciski pieczęci proboszczów wielkością odpowiadają pieczęciom sygnetowym $(20 \mathrm{~mm})$. We wszystkich przypadkach pieczęć jest nośnikiem informacji na temat funkcji pełnionej przez jej dysponenta. Cechą wspólną dla tej grupy są odwołania do kościelnych oznaczeń rangowych. W przypadku biskupów były to kapelusze $\mathrm{z}$ dwudziestoma chwostami, insygnia

27 HR, sygn. 134, s. 133 .

28 Ibidem, s. 38.

29 Ibidem, s. 44. Odcisk pieczęci A. Kukiela również na stronie 49.

30 J. Geresz, Z dziejów kościoła Św. Mikołaja w Międzyrzecu Podlaskim, Międzyrzec Podlaski 1997, s. 12.

31 Ibidem, s. 123 
władzy biskupiej - infuły i pastorały, w wizerunkach pieczęci proboszczów - kapelusze z dwunastoma chwostami. Poza odniesieniami do sprawowanych funkcji pieczęcie duchownych nie odbiegają od pieczęci szlacheckich o urzędniczym czy osobistym charakterze. W polu pieczęci znajdują się herby dysponentów, w przypadku pieczęci biskupów o dysponencie i pełnionej przez niego funkcji świadczy również legenda.

W grupie pieczęci osobistych urzędników świeckich wymienić należy pieczęcie starostów. W trakcie kwerendy rozpoznano pieczęcie herbowe dwóch starostów mielnickich, obie znajdują się wśród dowodów do księgi hipotecznej majątku międzyrzeckiego ${ }^{32}$.

Pierwszy z nich to Karol Józef Sedlnicki herbu Odrowąż (1703-1761), starosta mielnicki w latach $1732-1738^{33}$. Odcisk pieczęci starosty zachował się na odpisie przywileju, na mocy którego Stefan Zbaraski ufundował cerkiew św. Mikołaja w Międzyrzecu. Odpis wykonano w 1736 r. ${ }^{34}$ (Kat. nr 9).

Drugi z rozpoznanych odcisków stempli to pieczęć starosty mielnickiego Adama Szydłowskiego herbu Lubicz ${ }^{35}$. Odnaleziono dwa odciski pieczęci Szydłowskiego. Jeden z nich znajduje się w księdze dóbr ziemskich Międzyrzec Miasto na dokumencie z $1789 \mathrm{r}^{36}$, drugi w księdze dóbr ziemskich Witulin na dokumencie Z 1791 r., dotyczącym konwentu w Leśnej Podlaskiej ${ }^{37}$ (Kat. nr 10 i 11).

${ }^{32}$ Ziemia mielnicka w województwie podlaskim, z głównym miastem Mielnik. Wyodrębniona z ziemi drohickiej w latach 30.i 40. XVI w. Od 1569 r. inkorporowana do Korony Królestwa Polskiego. Na terenie ziemi mielnickiej dwa miasta królewskie - Mielnik i Łosice, były siedzibami starostw, pozostałe, w tym Międzyrzec i Rossosz - ośrodkami dóbr prywatnych. Graniczyła z ziemiami: bielską, drohicką i brzeską. Zob. D. Michaluk, Ziemia mielnicka województwa podlaskiego w XVI-XVII wieku, Toruń 2020.

${ }^{33}$ Karol Józef Sedlnicki herbu Odrowąż (1703-1761), podskarbi wielki koronny (od 1745 r.), podskarbi nadworny koronny (od 1736), wojewoda podlaski (od 1739). Wywodził się z rodu morawsko-śląskiego. Wychowywał się w Witulinie, majątku należącym do jego matki - Marii Kazimiery z Pieniążków. Jego żoną była Konstancja z Branickich. Zmarł w Konstantynowie. Kawaler Orderu Orła Białego. Pieczętował się herbem matki. Zob. H. Palkij, Karol Józef Sedlnicki, PSB, t. 36, 1995-1996, s. 144-148.

${ }^{34}$ HR, sygn. 134, s. 348-349.

${ }^{35}$ Adam Szydłowski herbu Lubicz (zm. 1820 r.), szambelan Stanisława Augusta Poniatowskiego w 1766 r., pokojowy królewski, rotmistrz Kawalerii Narodowej, starosta mielnicki. Odznaczony Orderem Orła Białego i Orderem św. Stanisława. Zob. Z. Zielińska, Adam Szydłowski, PSB, t. 49, 2014, s. 584-589.

${ }^{36} \mathrm{HR}$, sygn. 134, s. 68.

$37 \mathrm{HB}$, sygn. 754, s. 592. 
Przykładem odcisku pieczęci w grupie stempli świeckich, urzędniczych jest pieczęć księcia Michała Kazimierza Ogińskiego. Michał Kazimierz Ogiński (1728180o), magnat doby oświecenia, pełnił, m.in. funkcje i godności: generał lejtnanta, hetmana Wielkiego Księstwa Litewskiego (w latach 1768-1793), wojewody wileńskiego (od 1764 r.), pisarza polnego litewskiego (od 1748 r.). Był kompozytorem, pisarzem i dramaturgiem. Pieczęć księcia znajduje się na dokumencie - patencie na porucznikostwo wystawionym Marcinowi Serwińskiemu w Warszawie 10 XII 1774 r. $^{38}$ (Kat. nr 12).

Przedstawione powyżej obiekty to przykłady pieczęci świeckich, urzędniczych, których dysponentami byli starostowie mielniccy, podskarbi nadworny koronny, hetman wielki litewski. Podobnie jak w przypadku pieczęci biskupich, zarówno inskrypcje, jak i wyobrażenia napieczętne dostarczają informacji na temat dysponenta oraz pełnionych przez niego funkcji. Oprócz wizerunku herbu znajdujemy tu więc np. podłożone pod tarczą klucze, symbol urzędniczy (pieczęć Karola Józefa Sedlnickiego, starosty mielnickiego, od 1736 podskarbiego nadwornego koronnego). Wielkość omówionych odcisków pieczęci wynosi od $60 \mathrm{~mm}$ do $55 \mathrm{~mm}$.

Tylko na podstawie wstępnych badań można stwierdzić, że znaczną część zasobu sfragistycznego w Oddziale w Radzyniu Podlaskim, pochodzącego z XVIII i XIX w., stanowią pieczęcie sygnetowe. Odciski pieczęci odnaleźć można w księgach hipotecznych, a także przy aktach notarialnych. Oprócz wspomnianych powyżej odcisków pieczęci duchownych, w dużej mierze są to pieczęcie właścicieli majątków położonych na terenie dzisiejszych powiatów: bialskiego, radzyńskiego, parczewskiego i łosickiego, ale także innych osób, występujących jako świadkowie w sprawie.

W zespole nr 410 „Hipoteka w Radzyniu Podlaskim” odnaleziono kilka odcisków pieczęci Potockich, właścicieli Radzynia Podlaskiego w II połowie XVIII w. Pieczęcią sygnetową uwierzytelniali wystawiane dokumenty, m.in. synowie Eustachego i Marianny z Kątskich, małżonków Potockich, którzy po śmierci rodziców kolejno przejmowali we władanie dobra radzyńskie. Na dokumentach dotyczących sprzedaży nieruchomości położonych na terenie miasta Radzynia oraz wsi wchodzących w skład klucza swoją pieczęć odcisnęli Kajetan oraz Jan Eryk Potocki. Z wyjątkiem jednego obiektu stan zachowania odcisków i ich czytelność nie są dobre.

Na akcie sprzedaży kamienicy zajezdnej położonej w Rynku miasta Radzynia, sporządzonym 24 VI 1777 r., podpisali się trzej bracia Potoccy. W 1777 r. - Kajetan,

\footnotetext{
${ }^{38}$ APL OR, Akta notariusza Józefa Domańskiego w Białej Podlaskiej, sygn. 4, s. 265.
} 
w 1779 r. - Stanisław Kostka, w 1786 - Jan Eryk. Jedynie odcisk pieczęci Jana Eryka Potockiego jest czytelny (Kat. nr 4$)^{39}$.

Kolejne pieczęcie właścicieli Radzynia to odciski z XIX w., a więc Anny z Zamoyskich Sapieżyny ${ }^{40}$, Anny z Sapiehów Czartoryskiej ${ }^{41}$ i jej męża Adama Jerzego Czartoryskiego ${ }^{42}$ oraz Stanisława Korwin Szlubowskiego ${ }^{43}$ (Kat. nr 15-17). Dokumenty, na których znajdują się odciski pieczęci, wchodzą w skład akt notariuszy radzyńskich oraz hipoteki radzyńskiej. Pieczęć Anny z Zamoyskich Sapieżyny znajduje się na dokumencie z 1833 r. Sapieżyna w imieniu córki, wówczas właścicielki dóbr radzyńskich, przekazywała nieruchomość Janowi Koch. Dokument, na którym swoją pieczęć odcisnęła Anna z Sapiehów Czartoryska, to pełnomocnictwo, którego udzieliła swojemu mężowi, Adamowi, upoważniając go do zarządzania dobrami radzyńskimi. Pełnomocnictwo wystawiono w Sieniawie 27 II 1823 r. Podpis oraz odcisk pieczęci Adama Jerzego Czartoryskiego znajduje się także na pełnomocnictwie. Czartoryski, upoważniony przez żonę do decydowaniu o losie majątku, upoważnił z kolei Kazimierza Sokołowicza do zawarcia umowy z Kajetanem Stodolnickim na wydzierżawienie folwarku w Białej (dobra radzyńskie). Dokument - pełnomocnictwo spisano w Puławach 10 VII 1824 r. Pieczęć sygnetowa kolejnego z dziedziców dóbr radzyńskich - Stanisława Szlubowskiego, znajduje się na dokumencie, w którym zezwala on na uregulowanie w hipotece okręgowej nieruchomości położonej na terenie miasta Radzynia. Dokument wystawiono w Radzyniu w dniu 10 / 22 XI 1844 r.

Pieczęcie osobiste - sygnetowe, odciskane w laku, zawierają wizerunki herbu rodowego dysponenta. W przypadku Potockich jest to herb Pilawa, Sapiehów herb Lis, Czartoryskich - herb Pogoń. Anna z Sapiehów Czartoryska podpisywane przez siebie dokumenty poświadczała pieczęcią z wyobrażeniem dwóch herbów herbu rodowego Sapiehów oraz herbu Czartoryskich. Pieczęć Szlubowskich to natomiast wizerunek herbu Korwin zwanego Ślepowronem.

\footnotetext{
${ }^{39}$ Ibidem, HR, sygn. III/384, s. 31 .

${ }^{40}$ HR, sygn. VII/495, s. 36, Pieczęć sygnetowa Anny z Zamoyskich Sapieżyny (herb Lis) na dokumencie $\mathrm{z} 1833 \mathrm{r}$.

${ }^{41}$ OR, Akta notariusza Franciszka Lubańskiego w Radzyniu Podlaskim (dalej: AnFL), sygn. 8, s. 196.

${ }^{42}$ Ibidem, Akta notariusza Augustyna Szczawińskiego w Radzyniu Podlaskim, sygn. 1, s. 565.

${ }^{43}$ Ibidem, HR, sygn. III/408.
} 
Pieczęć sygnetowa uwierzytelnia również dokument wystawiony przez Elżbietę z Branickich Sapieżynę (1734-180o) ${ }^{44}$. Dokument, który dotyczył nadania gruntu cerkwi w należących do Sapiehów Dobratyczach, został sporządzony 21 IV 1771 r. Znajduje się wśród załączników do księgi hipotecznej dóbr ziemskich Dobratycze ${ }^{45}$. Pieczęć Elżbiety Sapieżyny przedstawia w polu pieczętnym dwie tarcze herbowe: po prawej stronie herb Lis Sapiehów oraz po lewej stronie herb Korczak Branickich (Kat. nr 19).

Pieczęcie sygnetowe zachowane w zasobie radzyńskiego archiwum to nie tylko źródło dotyczące właścicieli i duchownych wywodzących się z rodzin szlacheckich związanych $\mathrm{z}$ regionem. $\mathrm{W}$ aktach, które poddano kwerendzie, natrafiono na odciski pieczęci osób, świadków w sprawie lub wierzycieli. Zachowane odciski stanowią źródło nie tylko do badań sfragistycznych, ale również dla osób zainteresowanych heraldyką.

W księdze dóbr ziemskich Witulin znajdują się odciski pieczęci osób, które zostały poproszone o poświadczenie dokumentu. Na dokumencie z 1796 r. swój podpis i pieczęć złożył Jan Chrzanowski herbu Nowina ${ }^{46}$ (Kat. nr 20). Natomiast w księdze dóbr ziemskich Dobratycze wśród załączników znajduje się plenipotencja wystawiona przez Ludwika księcia Jabłonowskiego, wierzyciela sum obciążających majątek Kazimierza Nestora Sapiehę ${ }^{47}$. Plenipotencja wystawiona na osobę Józefa Pękosławskiego w 1842 r. została podpisana przez księcia. Dodatkowym uwierzytelnieniem dokumentu stał się odcisk pieczęci sygnetowej (Kat. nr 21).

Odrębną grupę pieczęci stanowią pieczęcie miejskie. Pochodzącym z zasobu radzyńskiego przykładem pieczęci miejskiej jest odcisk pieczęci miasta Radzynia z XVIII w. W zasobie radzyńskiego archiwum odnaleziono kilka odcisków tego stempla. Zostały wykonane w różnym materiale. Są to odciski w tuszu oraz w wosku przez opłatek. Z uwagi na materiał najbardziej czytelna jest pieczęć wykonana w tuszu.

W inskrypcjach napieczętnych pieczęci miejskich z XIV-XVII w. oraz pierwszej połowy wieku XVIII posługiwano się językiem łacińskim. Legendy składały się najczęściej z kilku określeń: „sigillum” lub skrót, słowo określające dysponenta

${ }^{44}$ Elżbieta z Branickich Sapieżyna (1734-180o) była siostrą Franciszka Ksawerego Branickiego. W 1753 r. poślubiła Jana Józefą Sapiehę z linii różańskiej, z którym się rozwiodła. W 1755 r. wyszła za mąż za Jana Sapiehę z linii kodeńskiej, z którym miała syna Kazimierza Nestora. Była zaangażowana w życie polityczne Rzeczypospolitej XVIII w.

${ }_{45}$ APL OR, HB, sygn. 435 A, s. 3.

${ }^{46}$ Ibidem, sygn. 754, s. 640, 650.

47 Ibidem, sygn. 435 A, b.p. 
pieczęci - „civitas” lub „oppidum”. Napis kończyła nazwa ośrodka. Do takich pieczęci możemy zaliczyć zachowaną pieczęć Radzynia (Kat. nr 22 i 23). Wspomina o niej wydawnictwo Pieczęcie i herby miejscowości woj. lubelskiego, przywołując odcisk z 1729 r. zachowany w zbiorach krakowskich ${ }^{48}$. Wszystkie pieczęcie, które odnaleziono w zasobie radzyńskiego Archiwum, uwierzytelniają dokumenty dotyczące spraw własnościowych mieszkańców miasta - akty sprzedaży gruntów, testament, dział majątkowy. Pochodzą z lat 1798 i $1799^{49}$ (Kat. nr 22).

Omówione odciski stempli są nie tylko przykładami znaków pieczętnych, ich formy i wizerunku, ale także źródłem wzbogacającym obraz historii lokalnej. Zaprezentowane w tekście obiekty to wybrane pieczęcie odnalezione w zasobie archiwum w Radzyniu Podlaskim. Nie jest to pełny i wyczerpujący zbiór, ale przegląd, który ma na celu pokazanie możliwości zasobu. Analiza materiałów aktowych pozwala przypuszczać, iż jest to zestaw reprezentatywny. Należy podkreślić, że wynik kwerendy jest ściśle związany z historią miejsca, jak również ze stopniem zachowania materiałów aktowych, w przypadku ksiąg hipotecznych z brakiem najstarszych dowodów dla większości jednostek. Szczególnie zespół archiwalny hipoteki w Radzyniu został pod tym względem uszczuplony. Dowody do ksiąg hipotecznych, w tym dokumenty składane podczas regulacji pierwiastkowej dóbr, zachowały się szczątkowo. Księga dowodów do dóbr międzyrzeckich, najstarsza w zespole, pokazuje, jakich obiektów sfragistycznych można by w nich szukać. Rozległość włości i ich historia sprawia, że wśród dokumentów odnaleźć można interesujące, często niezachowane w innych egzemplarzach źródła. O wiele lepiej pod tym względem zachowały się materiały hipoteki bialskiej. Cenne odciski odnaleziono również $\mathrm{w}$ księgach nieruchomości miejskich i wiejskich oraz w aktach notarialnych z XIX w.

Pieczęcie, których odciski odnaleźć można na materiałach archiwalnych przechowywanych w Oddziale w Radzyniu Podlaskim nie były do tej pory poddane szczegółowej kwerendzie oraz opracowaniu i ewidencji. Przystępując do prac ewidencyjnych z pewnością należałoby wydzielić i skatalogować najstarsze obiekty. $\mathrm{Na}$ odrębne potraktowanie i opracowanie zasługują również odciski stempli z XIX i XX w. W tym przypadku jednak, z uwagi na ilość i charakter materiału, katalogowanie należałoby poprzedzić selekcją.

${ }^{48}$ M. Gumowski, Pieczęcie i herby miejscowości województwa lubelskiego, Lublin 1959.

49 AnFL, sygn. 3, s. 492; ibidem, HR, sygn. III/376, s. 96. 


\section{Summary}

\section{Seal Imprints in the Collection of the State Archives in Lublin Branch in Radzyń Podlaski}

The subject of the article is the oldest seal imprints which are included in the collection of the State Archives in Lublin, Branch in Radzyń Podlaski. The study presents the seals of priests - bishops and parish priests of parishes connected with the Międzyrzecz estate, the seals of lay officials - Mielnik starosts (county officials), noblemen, and gentry, including the owners of landed estates. The city seal is represented by an $18^{\text {th }}$-century seal imprint of Radzyń. Bernard Maciejewski, the bishop of Lutsk, Franciszek Antoni Kobielski, the bishop of Lutsk and Brest, Teofil Godebski, the bishop of Volodymyr (Włodzimierz) and Brest, priest Adam Kukiel, Międzyrzec parish priest, Łukasz Opaliński, Michał Kazimierz Ogiński, Elzbieta Sapieżyna nee Branicka, Jan Eryk Potocki, starosts Karol Józef Sedlnicki and Adam Szydłowski were inter alia, the users of personal seals. Sigillography materials come from the collection of mortgage and notarial deeds. The article is enriched by the catalogue of seals imprinted in these records; in the catalogue the basic external features of each of them were discussed in accordance with the principles applied in other sigillographic editions of this type.

\section{Katalog pieczęci}

Podczas przygotowania opisu pieczęci uwzględniono zasady sformułowane w wytycznych, które weszły w życie na mocy Zarządzenia Nr 8 Naczelnego Dyrektora Archiwów Państwowych z 22 maja 1961 r. w sprawie wytycznych do opracowania zbiorów pieczęci przechowywanych $w$ archiwach państwowych ${ }^{50}$. Wybór powyższy podyktowany był wstępnym charakterem badań nad zasobem sfragistycznym Oddziału w Radzyniu Podlaskim oraz związaną z tym niepełną wiedzą na jego temat. Wzór opracowanej wówczas karty inwentarzowej uznano więc za optymalny. W tym miejscu należy jednak zaznaczyć, że w sytuacji podjęcia prac związanych z opracowaniem i inwentaryzacją zasobu sfragistycznego Oddziału należałoby kierować się wypracowanymi w ostatnich latach modelami opisu

${ }^{50}$ Zbiór przepisów archiwalnych wydanych przez Naczelnego Dyrektora Archiwów Państwowych w latach 1952-2000. 
pieczęci, zwłaszcza projektem wskazówek, który jest wynikiem pracy zespołu naukowego powołanego przez Naczelnego Dyrektora Archiwów Państwowych $\mathrm{w} 2008 \mathrm{r}^{51}$ Takie rozwiązanie będzie wskazane zwłaszcza $\mathrm{z}$ uwagi na fakt, że stosowana do opisu pieczęci karta inwentarzowa NDAP-0-3 nie oddaje w pełni bogactwa informacji, jakie niosą ze sobą pieczęcie ${ }^{52}$.

W przygotowanym zestawieniu opis jednostki (odcisku) odpowiada polom zaproponowanym w 1961 r. w karcie inwentarzowej. Kolejno wymieniono więc dane dotyczące: dysponenta, zespołu archiwalnego i sygnatury dokumentu, do którego należy pieczęć, opisu legendy i wyobrażenia napieczętnego oraz datacji dokumentu. Kolejne dane dotyczą opisu fizycznego odcisków pieczęci, a także stanu zachowania (opis konserwatorski). Ubytki, niezależnie od ilości brakujących znaków uzupełniano w oparciu o dane z dokumentu i literaturę bądź, jeśli nie było to możliwe, sygnalizowano trzema kropkami w nawiasie kwadratowym.

1.

Dysponent:

Bernard Maciejowski, biskup łucki

Zespół: Hipoteka w Białej Podlaskiej

Sygnatura: 204

Legenda: [nieczytelna]

Opis wyobrażenia: [nieczytelny] Widoczny zarys na pieczęci świadczyć może, że tarcza herbowa zwieńczona była infułą z zawiniętymi wstęgami.

Datacja dokumentu: Janów, 11 II 1600 r.

\section{Opis fizyczny:}

Okrągła, $50 \mathrm{~mm}$

Odcisk w wosku

Barwa materiału: czerwona

Mocowanie: sznur jedwabny pleciony - nici wielobarwne

Opis konserwatorski: stan zachowania dobry

\footnotetext{
${ }^{51}$ Wskazówki metodyczne do opracowania materiałów sfragistycznych $w$ zasobie archiwów państwowych, [w:] Opracowanie materiałów sfragistycznych, s. 97-219.

${ }^{52} \mathrm{Na}$ fakt powyższy zwrócono uwagę podczas prac badawczych nad problemem opisu pieczęci podjętych przez środowisko naukowe z Wrocławia. Zob. J. Jankowska, Metodyka opracowania archiwalnego pieczęci, s. 75.
} 
2.

Dysponent:

Franciszek Antoni Kobielski, biskup łucki i brzeski

Zespół: Hipoteka w Radzyniu Podlaskim

Sygnatura: 134 , s. 26

Legenda: $\{$ linia ciagła $\}$ (dywizor) + [F]RANCI(sci) ANTON(ius) IN DMENIN KOBIELSKI EPISCOPI LVCEOVIEN(sis) ET [...] // \{linia ciagła\} BRESTEN : SACRAE : REGINAE MAIES(tatis) : CANCELLARIVS (gałazka) - napis majuskułą, alfabet łaciński

Opis wyobrażenia: $\mathrm{W}$ polu pieczęci, oddzielonym od legendy ciągłą linią, pod kapeluszem z dwudziestoma chwostami (po dziesięć z każdej strony), owalna tarcza herbowa $\mathrm{z}$ herbem Poraj. Nad tarczą korona oraz infuła i pastorał krzywaśnią zwrócony do wewnątrz. Poniżej tarczy symbol orderu.

Datacja dokumentu: Janów, 1739 r.

Opis fizyczny:

Okrągła, śr. $50 \mathrm{~mm}$

Odcisk przez papier

Materiał odcisku: opłatek

Opis konserwatorski: stan zachowania dobry

3 .

Dysponent:

Franciszek Antoni Kobielski, biskup łucki i brzeski

Zespół: Hipoteka w Białej Podlaskiej

Sygnatura: poz. 754, s. 606

Legenda: $\{$ linia ciagła $\}$ (dywizor) $+[$ F]RANCI(sci) ANTON(ius) IN DMENIN KOBIELSKI EPISCOPI LVCEOVIEN(sis) ET [...] // \{linia ciagła\} BRESTEN : SACRAE : REGINAE MAIES(tatis) : CANCELLARIVS ( gałazka) - napis majuskułą, alfabet łaciński

Opis wyobrażenia: \{linia ciagła $\} \mathrm{W}$ polu pieczęci, pod kapeluszem $\mathrm{z}$ dwudziestoma chwostami (po dziesięć z każdej strony), owalna tarcza herbowa z herbem Poraj. Nad tarczą korona oraz infuła i pastorał krzywaśnią zwrócony do wewnątrz. Poniżej tarczy symbol orderu. 
Datacja dokumentu: Janów, 1 III 1749 r.

Opis fizyczny:

Okrągła, śr. 50 mm

Odcisk przez papier

Materiał odcisku: wosk

Barwa materiału: czerwona

Opis konserwatorski: stan zachowania dobry

4 .

Dysponent:

Józef Olszański, biskup serreński, sufragan chełmski, administrator diecezji łuckiej

Zespół: Hipoteka w Radzyniu Podlaskim

Sygnatura: 134 , s. 183

Legenda: [anepigraf]

Opis wyobrażenia: $\{$ feston $\} \mathrm{W}$ polu pieczęci obwiedzionym pasem, na którym u góry znajdują się dywizory między dwoma kropkami (krzyżyk) (gwiazdka?) (krzyżyk), niżej dwie przewiązane u dołu gałązki palmowe. \{linia perełkowa\} $\mathrm{W}$ polu centralnym pod kapeluszem $\mathrm{z}$ dwudziestoma chwostami (po dziesięć z każdej strony) - owalna tarcza herbowa z nieczytelnym godłem. Nad tarczą symbole władzy biskupiej - infuła i pastorał krzywaśnią zwrócony na zewnątrz.

Datacja dokumentu: ok. 1735 r.

Opis fizyczny:

Okrągła, śr. $45 \mathrm{~mm}$

Odcisk przez papier

Materiał odcisku: opłatek

Opis konserwatorski: stan zachowania dobry

5 .

Dysponent:

Teofil Godebski, biskup włodzimierski i brzeski

Zespół: Hipoteka w Radzyniu Podlaskim

Sygnatura: 134, s. 133 
Legenda: $\{$ feston\} \{podwójna linia ciagła\}[...] (G)ODZIE ·GODEBSKI [...] WLO [...] - napis majuskułą, alfabet łaciński

Opis wyobrażenia: \{podwójna linia ciagła $\} \mathrm{W}$ polu pieczęci, pod kapeluszem z dwudziestoma chwostami (po dziesięć z każdej strony), tarcza z godłem Godziemba, które przedstawia w polu czerwonym sosnę, o trzech koronach i zapewne pięciu korzeniach. W klejnocie pół rycerza w zbroi, trzymającego w prawej ręce taką samą sosnę. Wprost nad tarczą korona herbowa o pięciu fleuronach.

Datacja dokumentu: 12 VII 1746 r.

Opis fizyczny:

Okrągła, śr. $55 \mathrm{~mm}$

Odcisk przez papier

Materiał odcisku: wosk

Barwa materiału: czerwony

Opis konserwatorski: stan zachowania dobry, z uwagi jednak na wszycie karty pieczęć widoczna fragmentarycznie

6.

Dysponent:

Tomasz de Stuart Haliburton, proboszcz bialski, administrator diecezji łuckiej Zespół: Hipoteka w Radzyniu Podlaskim

Sygnatura: 134 , s. 38

Legenda: [anepigraf]

Opis wyobrażenia: \{podwójna linia ciągła\} $\mathrm{W}$ polu pieczęci, pod kapeluszem $\mathrm{z}$ dwunastoma chwostami (po sześć $\mathrm{z}$ każdej strony), znajduje się tarcza herbowa. Pole tarczy okryte pionowym szrafirunkiem, $\mathrm{w}$ tarczy pas z trzema sześciopromiennymi gwiazdami. Nad tarczą stylizowany hełm z labrami w formie wici. Poniżej krzyż kawalerski o ramionach zdobionych perłami zawieszonymi na łańcuchu. Datacja dokumentu: Janów, 15 II 1799 r.

Opis fizyczny:

Okrągła, śr. $50 \mathrm{~mm}$

Odcisk w papierze

Materiał odcisku: papier

Opis konserwatorski: stan zachowania dobry 
7.

Dysponent:

Adam Kukiel, duchowny, proboszcz parafii pw. Świętego Mikołaja w Międzyrzecu Zespół: Hipoteka w Radzyniu Podlaskim

Sygnatura: 134 , s. 44

Legenda: [anepigraf]

Opis wyobrażenia: $\mathrm{W}$ polu pieczęci, pod kapeluszem $\mathrm{z}$ dwunastoma chwostami (po sześć po każdej stronie), znajduje się tarcza z godłem Leliwa. Pole tarczy okryte poziomym szrafirunkiem. W klejnocie na pawim ogonie powtórzone godło. Nad tarczą korona herbowa szlachecka. Pod tarczą krzyż kawalerski.

Datacja dokumentu: Międzyrzec, 21 IV 1803 r.

Opis fizyczny:

Owalna, 20×15 mm

Odcisk na papierze

Materiał odcisku: lak

Barwa materiału: czerwona

Opis konserwatorski: odcisk ukruszony, widoczne pęknięcia

8.

Dysponent:

Daniel Śnitko, duchowny, proboszcz parafii unickiej w Dołdze

Zespół: Hipoteka w Radzyniu Podlaskim

Sygnatura: 134, s. 123

Legenda: [anepigraf]

Opis wyobrażenia: $\mathrm{W}$ polu pieczęci, pod kapeluszem $\mathrm{z}$ dwunastoma chwostami (po sześć z każdej strony), owalna tarcza herbowa. Na tarczy znajduje się godło: głowa wilka? trzymająca ptasią łapę? Nad tarczą korona herbowa szlachecka. Powyżej herbu znajdują się litery T? / X / S rozdzielone koroną herbową.

Datacja dokumentu: Dołha, 30 VII 1802 r.

Opis fizyczny:

Owalna, 20×15 mm

Odcisk na papierze 
Materiał odcisku: lak

Barwa materiału: czerwona

Opis konserwatorski: odcisk ukruszony, widoczne pęknięcia

9.

Dysponent:

Karol Józef Sedlnicki, starosta mielnicki

Zespół: Hipoteka w Radzyniu Podlaskim

Sygnatura: 134 , s. 348-349

Legenda: $\{\text { linia ciagła }\}^{*}[\mathrm{~K}]$ AROLVS IOSEFIIVS ODROWAZ SIEDLNICKI [...] $\mathrm{S}(u b)$ THESAVRARIVS CVRIAE [...] MIELNICE(nsis) CAP(itaneus) ${ }^{*}$ - napis majuskułą, alfabet łaciński

Opis wyobrażenia: $\{$ linia ciągła $\}$ W polu pieczęci ozdobna tarcza z godłem Odrowąż. Pole tarczy okryte pionowym szrafirunkiem. Na tarczy: strzała z końcami na obie strony zakrzywionymi. Nad tarczą korona. Pod tarczą klucze oraz trzymacze herbowe - dwa podtrzymujące tarczę orły, które stoją na postumentach połączonych u dołu podstawami.

Datacja dokumentu: $1736 \mathrm{r}$.

Opis fizyczny:

Okrągła, $60 \mathrm{~mm}$

Odcisk przez papier

Materiał odcisku: opłatek

Barwa materiału: bezbarwna

Opis konserwatorski: stan zachowania dobry

10.

Dysponent:

Adam Szydłowski, starosta mielnicki

Zespół: Hipoteka w Radzyniu Podlaskim

Sygnatura: 134 , s. 68

Legenda: $\{\text { feston? }\}^{*}[\ldots][$ SZ]YDLOW[SKI] [...] [C]APITANEUS [...] - napis majuskułą, alfabet łaciński 
Opis wyobrażenia: \{linia ciagła $\} \mathrm{W}$ polu pieczęci ozdobna tarcza z herbem Lubicz podkowa z krzyżem kawalerskim zaćwieczonym na barku i takim samym krzyżem w środku podkowy. Na tarczy korona hrabiowska. W klejnocie trzy pióra strusie. Tarcza opleciona wstęgą orderową, za tarczą panoplia. Pod tarczą Order Świętego Stanisława.

Datacja dokumentu: 12 VIII $1789 \mathrm{r}$.

\section{Opis pieczęci:}

Owalna, $55 \times 50 \mathrm{~mm}$

Odcisk na papierze

Materiał odcisku: papier

Opis konserwatorski: Stan zachowania dobry

11.

Dysponent:

Adam Szydłowski, starosta mielnicki

Zespół: Hipoteka w Białej Podlaskiej

Sygnatura: 754, s. 592

Legenda: $\{$ feston?\}`ADAMUS IN SZYD[LOW] SZYDLOWSK[I] [...] - napis majuskułą, alfabet łaciński

Opis wyobrażenia: \{linia ciagła $\} \mathrm{W}$ polu pieczęci ozdobna tarcza z herbem Lubicz podkowa z krzyżem kawalerskim zaćwieczonym na barku i takim samym krzyżem w środku podkowy. Na tarczy korona hrabiowska. W klejnocie trzy pióra strusie. Tarcza opleciona wstęgą orderową, za tarczą panoplia. Pod tarczą Order Świętego Stanisława.

Datacja dokumentu: $1791 \mathrm{r}$.

\section{Opis pieczęci:}

Owalna, $55 \times 50 \mathrm{~mm}$

Odcisk na papierze

Materiał odcisku: papier

Opis konserwatorski: stan zachowania dobry 
12.

Dysponent:

Michał Kazimierz Ogiński, Książę, hetman Wielkiego Księstwa Litewskiego

Zespół: Akta notariusza Józefa Domańskiego w Białej Podlaskiej

Sygnatura: 5 , s. 265

Legenda: $\{$ feston $\}$ \{linia ciagła $\}{ }^{*}$ MICHAEL ${ }^{\star}$ CASIMIRUS.OGINSKI* SUPREM US.DUX.EXERCITUUM·MAG(nus).DUC(atus).L(ituaniae ) * - napis majuskułą, alfabet łaciński

Opis wyobrażenia: \{podwójna linia ciągła\} W polu pieczęci owalna tarcza herbowa na płaszczu zwieńczonym mitrą książęcą. W tarczy herb Oginiec przedstawiający bramę obozu wojennego, nad nią rozdarty krzyż. Pod tarczą krzyż Orderu Orła Białego, którego łańcuch obiega tarczę.

Datacja dokumentu: Warszawa, 10 XII 1774 r.

Opis pieczęci:

Okrągła, śr. $55 \mathrm{~mm}$

Odcisk przez papier

Materiał odcisku: wosk

Barwa materiału: czerwona

Opis konserwatorski: stan zachowania dobry, delikatne przetarcie na tarczy herbowej

13.

Dysponent:

Łukasz Opaliński, właściciel dóbr Międzyrzec

Zespół: Hipoteka w Radzyniu Podlaski

Sygnatura: 134, s. 92

Legenda: \{linia ciagła + LVCAS DE BNIN OPALINSKI MARESALCVS CVRIAE REGNI (listek) - napis majuskułą, alfabet łaciński

Opis wyobrażenia: \{linia ciagła\} W polu pieczęci tarcza herbowa z godłem Łodzia, poniżej u podstawy tarczy uskrzydlona główka - putto. Nad nim klejnot - na pawim ogonie powtórzone godło.

Datacja dokumentu: 27 X 1659 r. 
Opis pieczęci:

Owalna, 40×34 mm

Odcisk przez papier

Materiał odcisku: wosk

Barwa materiału: czerwona

Opis konserwatorski: stan zachowania średni

14 .

Dysponent:

Jan Eryk Potocki, właściciel dóbr klucza radzyńskiego

Zespół: Hipoteka w Radzyniu Podlaskim

Sygnatura: III/384, s. 31

Legenda: [anepigraf]

Opis wyobrażenia: $\mathrm{W}$ polu pieczęci tarcza herbowa z godłem Pilawa. Pole tarczy pokryte szrafirunkiem poziomym, nad tarczą hełm zwieńczony koroną hrabiowską (dziewięciopałkową).

Datacja dokumentu: Radzyń, 7 IX 1786 r.

\section{Opis pieczęci:}

Owalna, ok. $28 \times 25 \mathrm{~mm}$

Odcisk na papierze

Materiał odcisku: lak

Barwa materiału: czerwona

Opis konserwatorski: stan zachowania średni, widoczne ukruszenia i liczne pęknięcia

15.

Dysponent:

Anna z Zamoyskich Sapieżyna, właścicielka dóbr ziemskich Radzyń

Zespól: Hipoteka w Radzyniu Podlaskim

Sygnatura: III/495, s. 36

Legenda: [anepigraf] 
Opis wyobrażenia: $\mathrm{W}$ polu pieczęci, na płaszczu zwieńczonym mitrą książęcą, tarcza, pod nią trzy krzyże orderowe zawieszone na wstęgach. Na tarczy herb Lis - strzała dwa razy przekrzyżowana, zwrócona żeleźcem do góry.

Datacja dokumentu: Warszawa, $8 \mathrm{~V} 1833 \mathrm{r}$.

\section{Opis pieczęci:}

Owalna, $18 \times 20 \mathrm{~mm}$

Odcisk na papierze

Materiał odcisku: lak

Barwa materiału: czerwona

Opis konserwatorski: stan zachowania dobry

16.

Dysponent:

Anna z Sapiehów Czartoryska, Księżna, właścicielka dóbr ziemskich Radzyń Zespół: Akta notariusza Franciszka Lubańskiego w Radzyniu Podlaskim Sygnatura: 8, s. 196

Legenda: [anepigraf]

Opis wyobrażenia: $\mathrm{W}$ polu pieczęci namiot heraldyczny, a na nim dwie tarcze zwieńczone mitrami książęcymi. Na tarczach: herb Czartoryskich (strona prawa) oraz herb Lis (strona lewa).

Datacja dokumentu: Sieniawa, 27 II 1823 r.

\section{Opis pieczęci:}

Owalna, $25 \times 20 \mathrm{~mm}$

Materiał odcisku: lak

Barwa materiału: czerwona

Opis konserwatorski: stan zachowania średni

17.

Dysponent:

Adam Jerzy Czartoryski, Książę

Zespół: Akta notariusza Augustyna Szczawińskiego w Radzyniu Podlaskim Sygnatura: 1, S. 565 
Legenda: [anepigraf]

Opis wyobrażenia: $W$ polu pieczęci namiot heraldyczny, na nim tarcza herbowa zwieńczona mitrą książęcą. Na tarczy herb Pogoń, który przedstawia rycerza na koniu wspiętym, z mieczem i tarczą, a pod nim, z prawej, trzy baszty. Tarczę podtrzymują trzymacze - postacie ludzkie podtrzymujące mniejsze tarcze z podwójnym krzyżem. Pod tarczą trzy ordery, poniżej których na wstędze dewiza heraldyczna: „BĄDŹ CO BĄDŹ”.

Datacja dokumentu: Puławy, 10 VII 1824 r.

Opis pieczęci:

Owalna, $33 \times 36 \mathrm{~mm}$

Odcisk na papierze

Materiał odcisku: lak

Barwa materiału: czerwona

Opis konserwatorski: stan zachowania średni, widoczne pęknięcia

18.

Dysponent:

Stanisław Korwin Szlubowski, właściciel dóbr ziemskich Radzyń

Zespół: Hipoteka w Radzyniu Podlaskim

Sygnatura: III/408, s. 31

Legenda: [anepigraf]

Opis wyobrażenia: $\mathrm{W}$ polu pieczęci tarcza herbowa o szerokim skraju, na której znajduje się godło herbu Ślepowron. Powyżej hełm z labrami. W klejnocie powtórzone godło.

Datacja dokumentu: Radzyń, 10/22 XI 1844 r.

Opis pieczęci:

Wymiary pieczęci: $20 \times 13 \mathrm{~mm}$

Kształt pieczęci: czworoboczna

Materiał odcisku: lak

Barwa materiału: czerwona

Opis konserwatorski: stan zachowania średni, widoczne ubytki i pęknięcia 
19.

Dysponent:

Elżbieta z Branickich Sapieżyna, właścicielka dóbr ziemskich Dobratycze

Zespół: Hipoteka w Białej Podlaskiej

Sygnatura: $435 \mathrm{~A}, \mathrm{~s} .3$

Legenda: [anepigraf]

Opis wyobrażenia: \{linia perełkowa $\{$ linia ciagła $\}$ W polu pieczętnym dwie owalne tarcze herbowe. Po prawej stronie tarcza zwieńczona mitrą książęcą z herbem Lis Sapiehów. Po lewej stronie tarcza z herbem Korczak Branickich. Nad tarczą korona o trzech fleuronach i dwóch perłach, w której znajduje się klejnot: pół szczenięcia wyżła.

Datacja dokumentu: 27 IV $1771 \mathrm{r}$.

Opis pieczęci:

Okrągła, śr. $25 \mathrm{~mm}$

Odcisk na papierze

Materiał odcisku: lak

Barwa materiału: czerwona

Opis konserwatorski: stan zachowania średni, widoczne pęknięcia

20.

Dysponent:

Jan Chrzanowski, herbu Nowina

Zespół: Hipoteka w Białej Podlaskiej

Sygnatura: 754 , s. 650

Legenda: [anepigraf]

Opis wyobrażenia: W polu pieczęci owalna tarcza z godłem herbu Nowina. Nad tarczą korona o trzech fleuronach i dwóch perłach z klejnotem: zbrojną golenią. Od góry tarcza ujęta w gałązki laurowe, od podstawy panoplia.

Datacja dokumentu: Witulin, 8 XI 1796 r.

Opis pieczęci:

Owalna, $23 \times 20 \mathrm{~mm}$

Odcisk na papierze 
Materiał odcisku: lak

Barwa materiału: czerwona

Opis konserwatorski: stan zachowania dobry

21.

Dysponent:

Ludwik Jabłonowski, Książę

Zespół: Hipoteka w Białej Podlaskiej

Sygnatura: 435A, b.p.

Legenda: [anepigraf]

Opis wyobrażenia: W polu pieczęci herb Prus III: w tarczy dwudzielnej w słup $\mathrm{w}$ polu prawym szrafirowanym poziomymi liniami - wilcza kosa ostrzem ku środkowi obrócona, w polu lewym szrafirowanym pionowymi liniami - pół podkowy z zaćwieczonym na nich półtora krzyżem, którego ramię dolne odwrócone w prawo. Tarcza herbowa zwieńczona mitrą książęcą. Pod tarczą krzyż orderowy. Datacja dokumentu: Wenecja, 22 IX $1842 \mathrm{r}$.

\section{Opis pieczęci:}

Czworoboczna, $25 \times 28 \mathrm{~mm}$

Odcisk na papierze

Materiał odcisku: lak

Barwa materiału: czerwona

Opis konserwatorski: stan zachowania średni, widoczne ubytki i pęknięcia

22.

Dysponent:

Pieczęć Miasta Radzynia, XVIII w.

Zespół: Akta notariusza Franciszka Lubańskiego w Radzyniu Podlaskim Sygnatura: 3, s. 492

Legenda: $\left\{\right.$ linia ciagła ${ }^{*}$ LOCVS SILL[...] - napis majuskułą, alfabet łaciński Opis wyobrażenia: \{podwójna linia ciągła\} W polu pieczęci wyobrażenie stojącego zwierzęcia (kozła ? niedźwiedzia ?).

Datacja dokumentu: Radzyń, 20 I 1798 r. 
Opis pieczęci:

Okrągła, śr. $28 \mathrm{~mm}$

Odcisk przez papier

Materiał odcisku: opłatek

Opis konserwatorski: stan zachowania dobry

23.

Dysponent:

Pieczęć Miasta Radzynia, XVIII w.

Zespół: Hipoteka w Radzyniu Podlaskim

Sygnatura: III/376, s. 96

Legenda: $\left\{\right.$ linia ciagła ${ }^{*}$ LOCVS [...] [RA]DZINENSIS - napis majuskułą, alfabet łaciński

Opis wyobrażenia: \{podwójna linia ciagła\} W polu pieczęci wyobrażenie stojącego zwierzęcia (kozła ? niedźwiedzia ?).

Datacja dokumentu: Stare Miasto Radzyń, V 1799 r.

\section{Opis pieczęci:}

Okrągła, śr. $28 \mathrm{~mm}$

Odcisk na papierze

Materiał odcisku: tusz

Barwa materiału: czarny

Opis konserwatorski: stan zachowania dobry.

\section{Bibliografia}

Adamczewski A., Pieczęcie urzędowe władz lokalnych z obszaru Polski centralnej, cz. 2, Pieczęcie sądów szlacheckich do 1793 roku, Łódź 2010.

Bednarek D., Sokołowska D., Żygadło D., Problem opisu pieczęci (w formacie FOPAR na podstawie kart inwentarzowych pieczęci A i B), [w:] Komputeryzacja Archiwów, t. 1, Problemy opracowania archiwaliów staropolskich $w$ skomputeryzowanych systemach informacyjnych, red. B. Ryszewski, Toruń 1994, s. 29-42.

Chojnacka K., Międzyarchiwalny katalog materiałów sfragistycznych, „Archeion” t. 73, 1982, s. 101-110. 
Dicianówna A., Kardynał Barnard Maciejowski jako opiekun uczonych i literatów, „Collectanea Theologica”, t. 15, 1934, s. 323-359.

Geresz J., Z dziejów kościoła św. Mikołaja w Międzyrzecu Podlaskim, Międzyrzec Podlaski 1997.

Gumowski M., Pieczęcie i herby miejscowości województwa lubelskiego, Lublin 1959.

Haisig M., Osiagnięcia i postulaty w zakresie sfragistyki polskiej, „Studia Źródłoznawcze”, t. 4, 1959, s. 153-168.

Haisig M., Sfragistyka ogólna, [w:] M. Gumowski, M. Haisig, S. Mikucki, Sfragistyka, Warszawa 1960.

Hlebionek M., Katalog pieczęci przy dokumentach samoistnych Archiwum Państwowego w Bydgoszczy, Warszawa 2012.

Hlebionek M., Kilka uwag o pieczęciach w XIX w. na przykładzie zaboru pruskiego, [w:] Nauki pomocnicze historii. Teoria, metody badań, dydaktyka, red. A. Jaworska, R. Jop, Warszawa 2013 s. 191-200.

Hlebionek M., O pieczęciach starosty generalnego Wielkopolski Adama Sędziwoja Czarnkowskiego, Archiwa - Kancelarie - Zbiory, t. 2, 2011, s. 11-61.

Hlebionek M., Pieczęć jako obiekt archiwalny, [w:] Toruńskie konfrontacje archiwalne, t. 2, red. W. Chorążyczewski, A. Rosa, Toruń 2011, s. 303-320.

Hlebionek M., Problemy opisu materiałów sfragistycznych w polskich archiwach, Cфpaгістичний щорічник, Вип. I, 2011, s. 222-251.

Hlebionek M., Standardy międzynarodowe w archiwalnym opisie materiałów sfragistycznych. Przykład francuski i włoski, [w:] Toruńskie konfrontacje archiwalne, t. 3, red. W. Chorążyczewski, A. Rosa, Toruń 2012, s. 219-249.

Hlebionek M., W stronę SIGILLUM. Problemy archiwalnego opisu pieczęci, „Archiwista Polski” 2006, nr 4, s. 19-26.

Łosowski J., Pieczęcie starostów chełmskich od drugiej połowy XVI do XVIII wieku, [w:] Pieczęć w Polsce średniowiecznej i nowożytnej. Zbiór studiów, Lublin 1998, s. 147-170.

Materiały do polskiego słownika sfragistycznego, oprac. A. Baniecki i in., „Archiwista Polski” 2010, nr 3 (59), s. 43-56.

Mazur P., Poczet biskupów chełmskich obrządku łacińskiego, Chełm 2012.

Michaluk D., Ziemia mielnicka województwa podlaskiego w XVI-XVII wieku, Toruń 2020.

Nabiałek K., Pieczęcie starostów księstw oświęcimskiego i zatorskiego do 1563 roku, „Roczniki Historyczne"85, 2019, s. 111-150.

Opracowanie materiałów sfragistycznych $w$ archiwach, red. P. Gut, M. Hlebionek, Warszawa 2020, ss. 219.

Palkij H., Karol Józef Sedlnicki, [w:] Polski słownik biograficzny, t. 36, 1995-1996, Warszawa - Kraków, s. 144-148. 
Piech Z., Perspektywy polskich badań sfragistycznych, [w:] Pieczęcie w dawnej Rzeczypospolitej. Stan i perspektywy badań, red. Z. Piech, J. Pakulski, J. Wroniszewski, Warszawa 2006, s. 31-58.

Szczygielski W., Kobielski Franciszek Antoni herbu Poraj (1679-1755), [w:] Polski słownik biograficzny, t. 13, 1967-1968, Wrocław-Warszawa-Kraków, s. 146-148.

Tylus S., W sprawie datacji śmierci niektórych biskupów kresowych, „Archiwa, Biblioteki i Muzea Kościelne”, t. 70, 1998, s. 357-360.

Vocabularium internationale sigillographicum, red. K. Müller, L. Vrtel, M. Hlebionek, V. Keresztes, tłum. na j. pol. B. Jusypenko, oprac. M. Hlebionek, A. Baniecki, D. Bednarek, R. Forysiak-Wójciński, J. Grabowski, P. Gut, P. Pokora, D. Żygadło, Bratislava 2016, ss. 608.

Wereda D., Biskupi unickiej diecezji włodzimiersko-brzeskiej w XVIII wieku, „Szkice Podlaskie, t. 9, 2001, s. 61-75.

Wędzki A., Problem genezy Międzyrzeca Podlaskiego na tle procesów urbanizacyjnych na południowo-zachodnim pograniczu Podlasia, „Rocznik Międzyrzecki”, t. 6, 1974 , s. 34-46.

Zbiór przepisów archiwalnych wydanych przez Naczelnego Dyrektora Archiwów Państwowych w latach 1952-200o, oprac. M. Tarakanowska, E. Rosowska, Warszawa 2001, s. 301.

Zielińska Z., Adam Szydłowski, [w:] Polski słownik biograficzny, t. 49, 2014, WarszawaKraków, s. 584-589. 

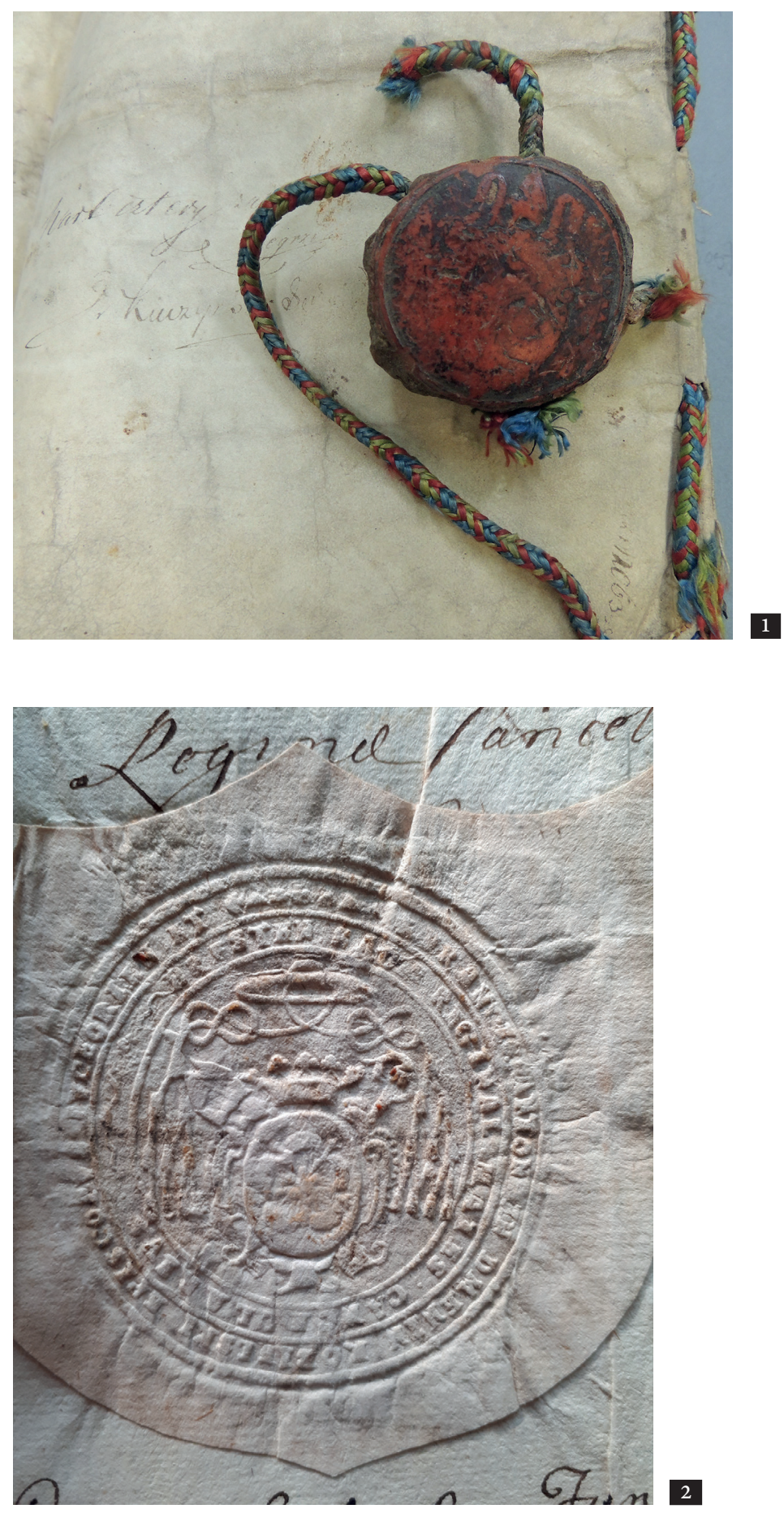
Pieczęcie z zasobu Archiwum Państwowego w Lublinie...
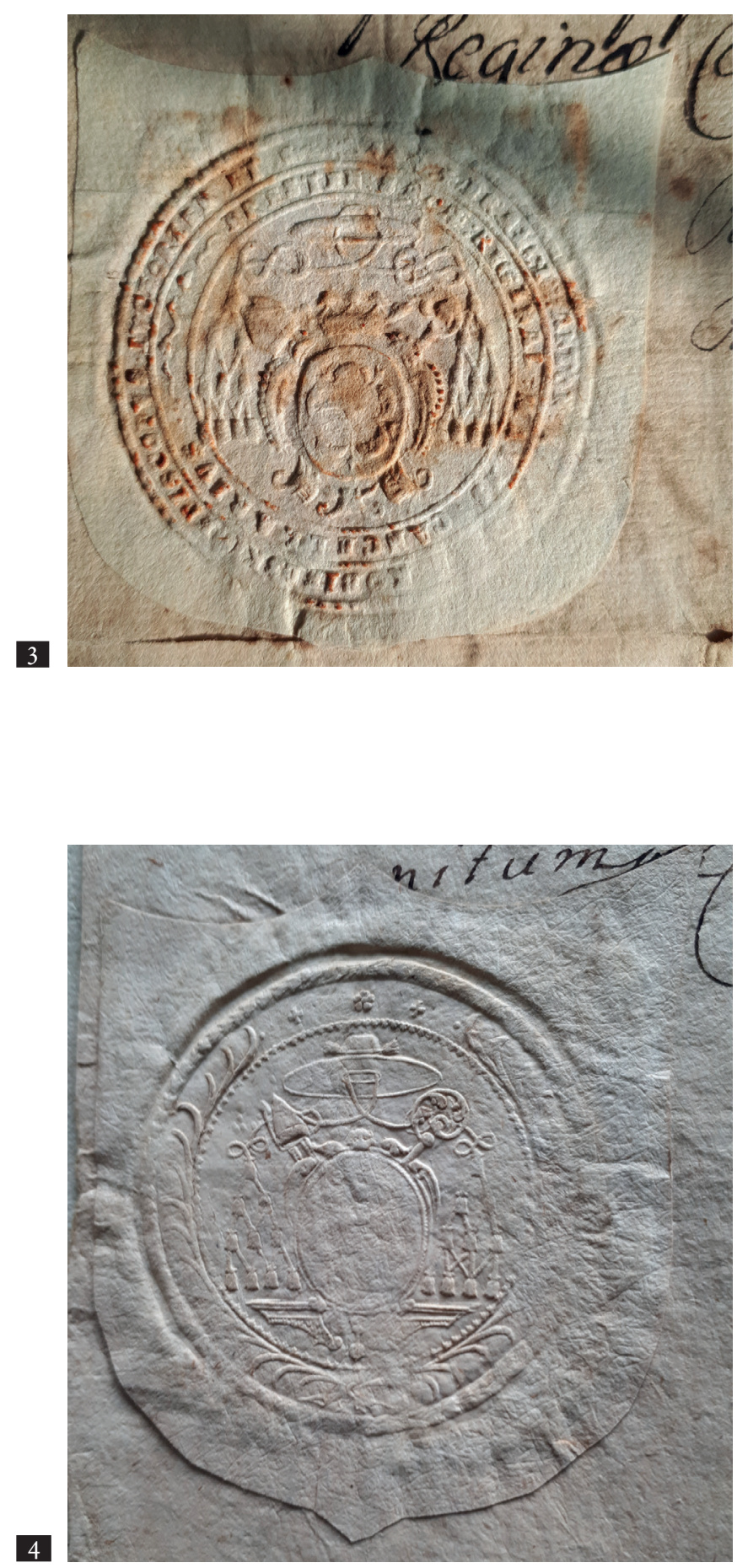

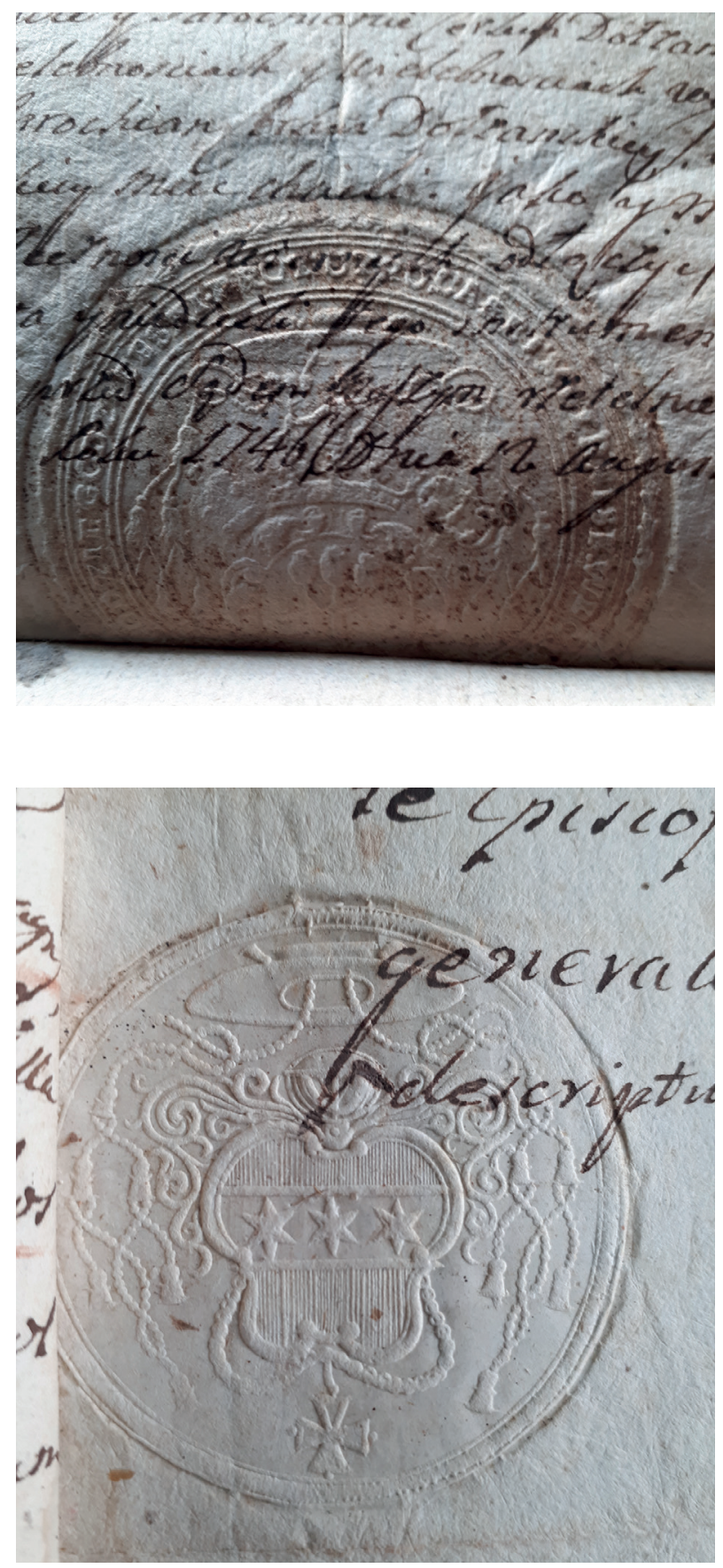

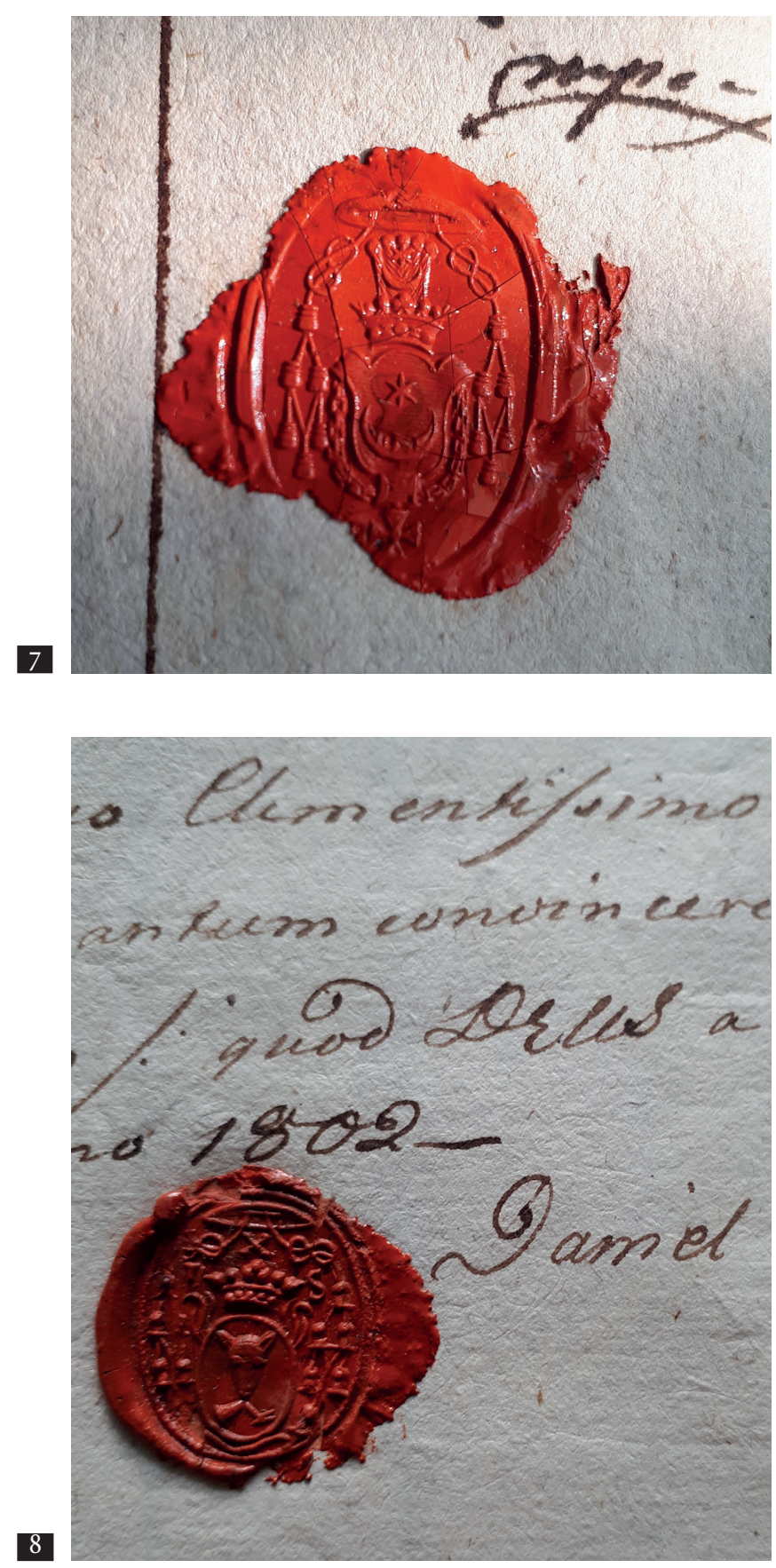
Joanna Kowalik-Bylicka
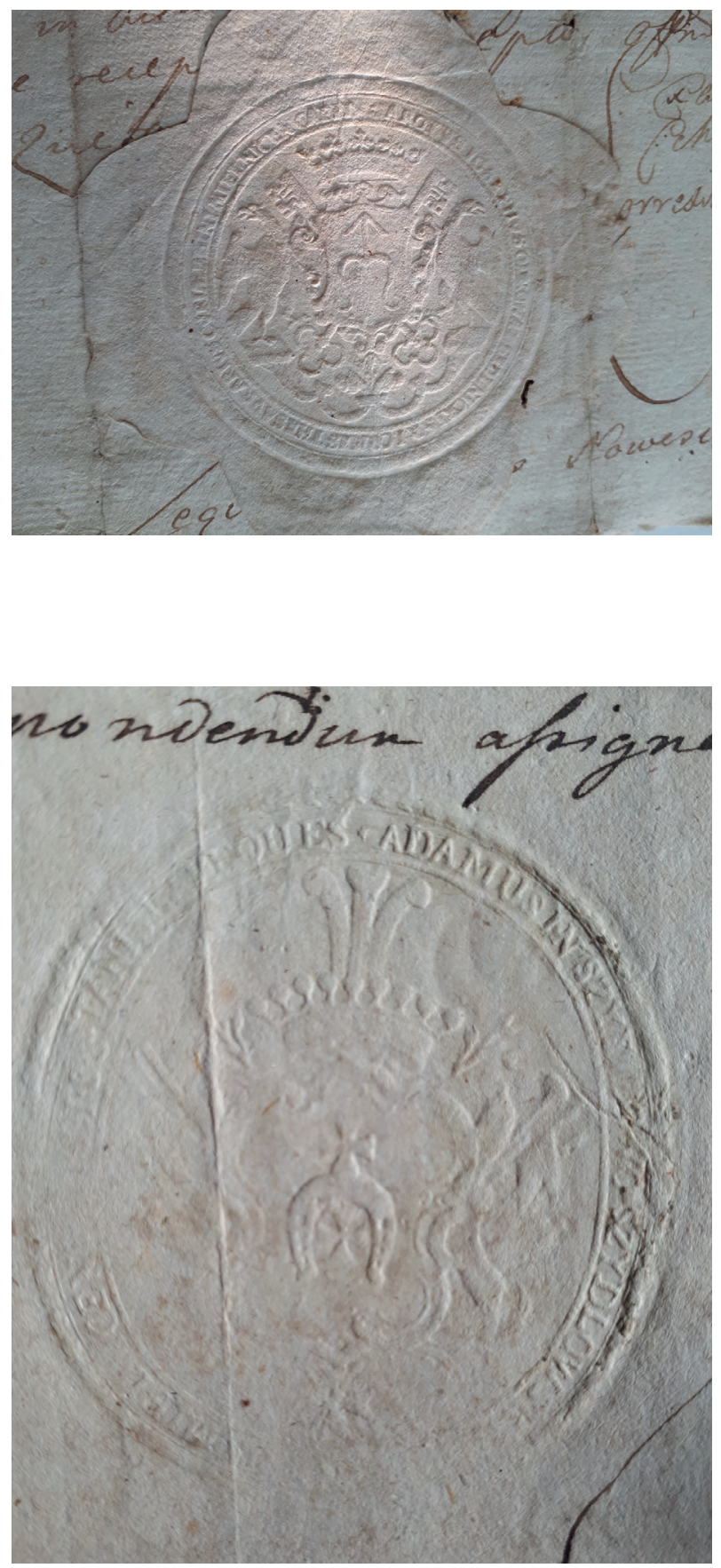

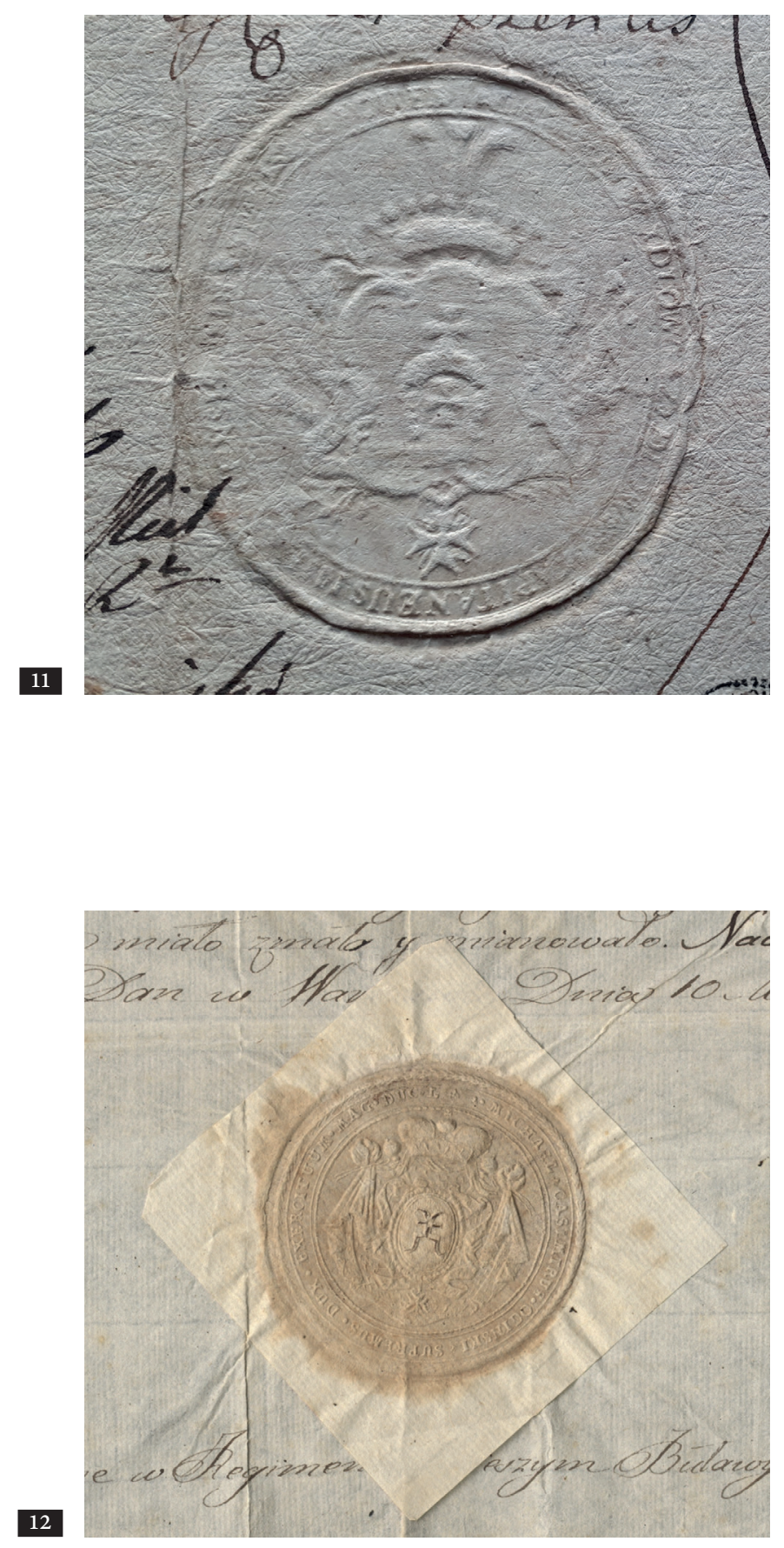
$216 \quad$ Joanna Kowalik-Bylicka
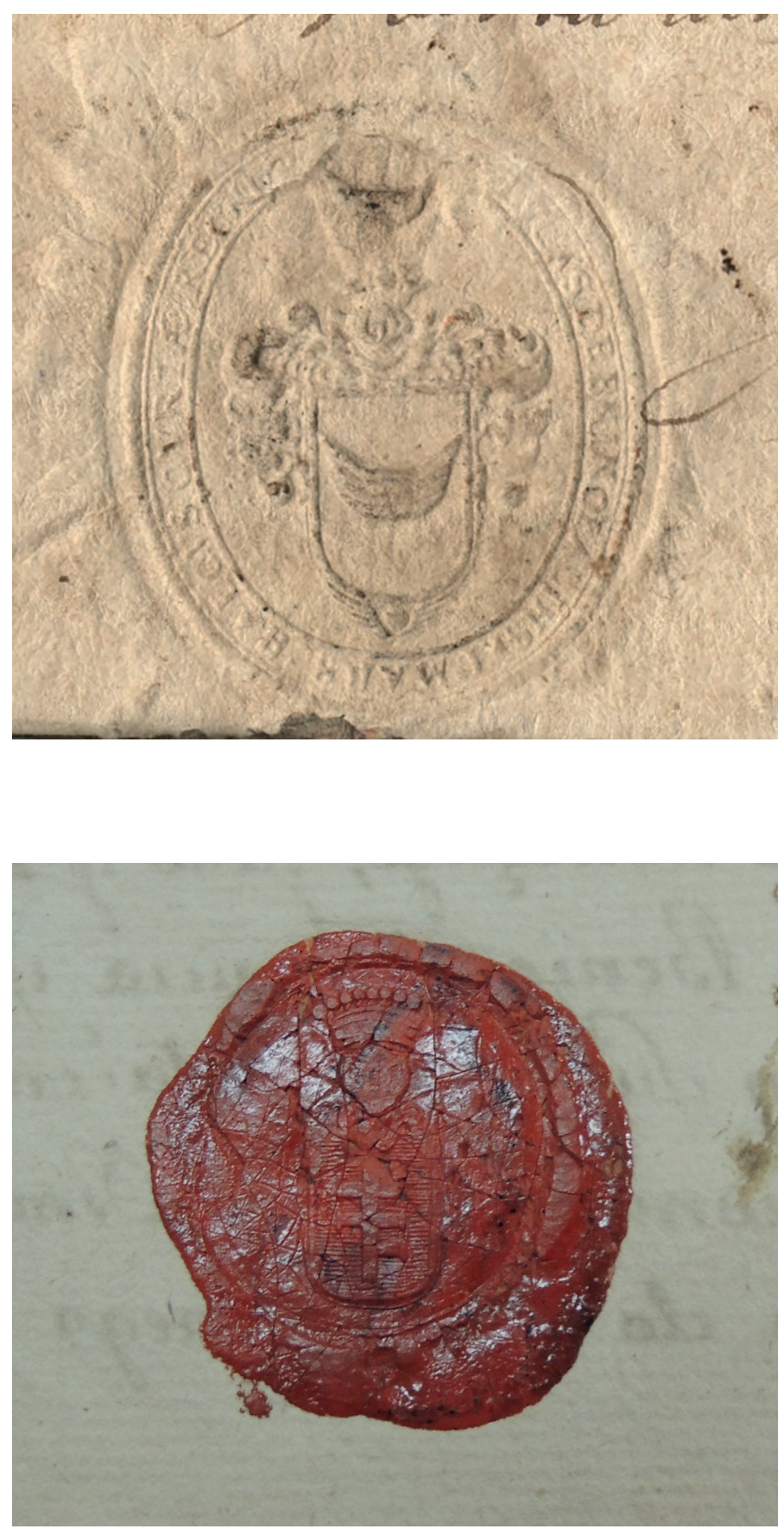

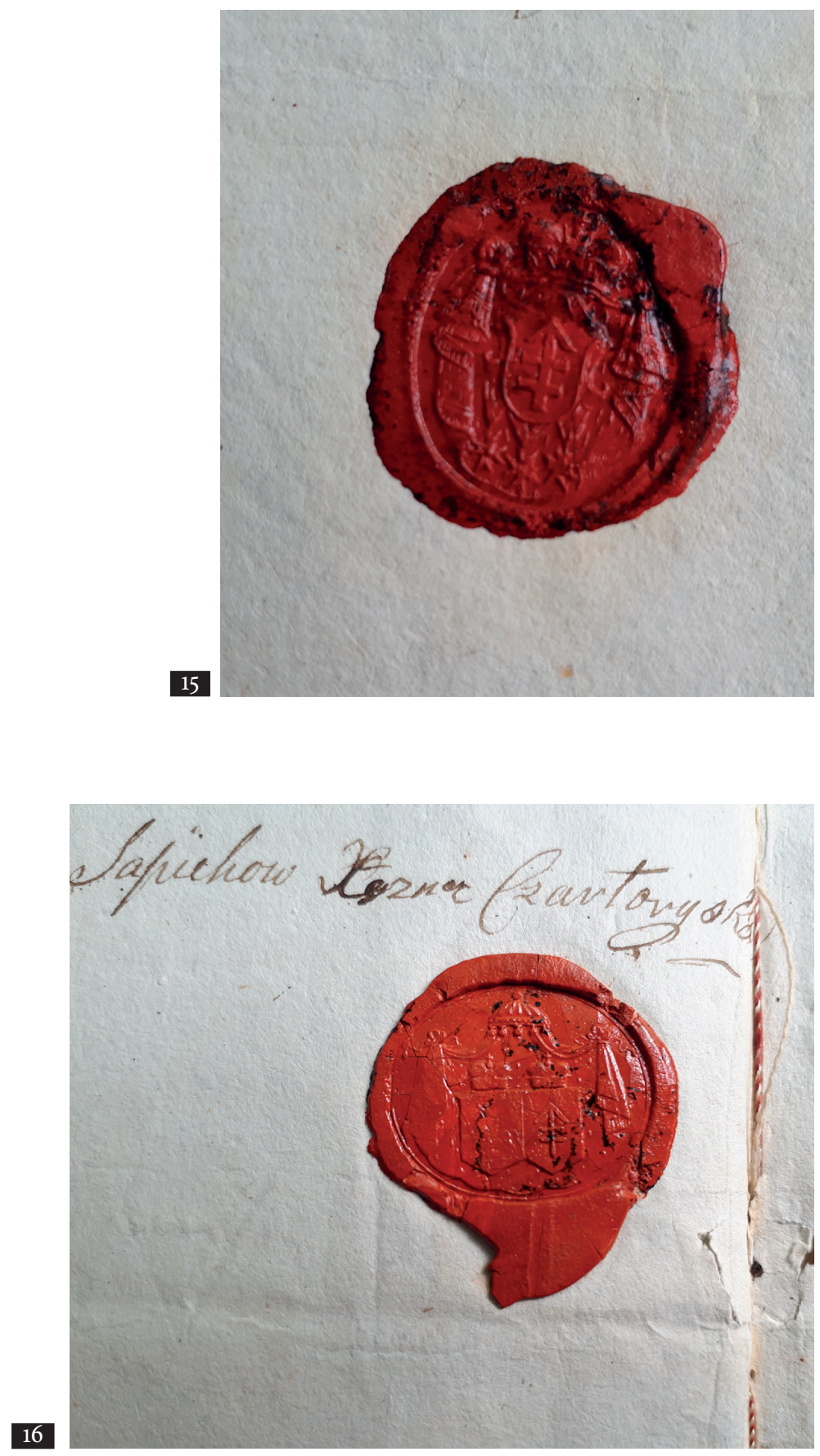
Joanna Kowalik-Bylicka

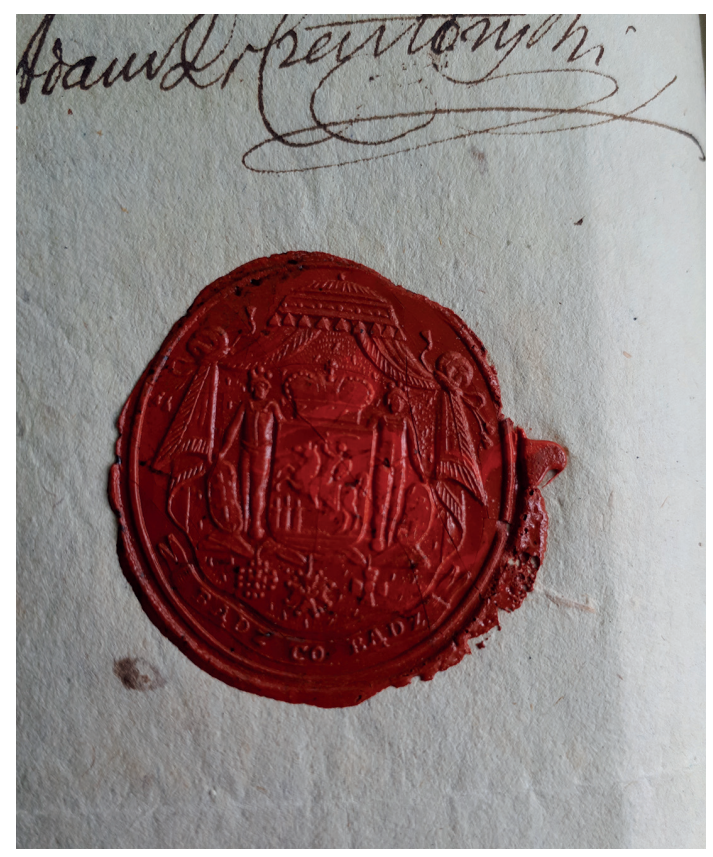

17

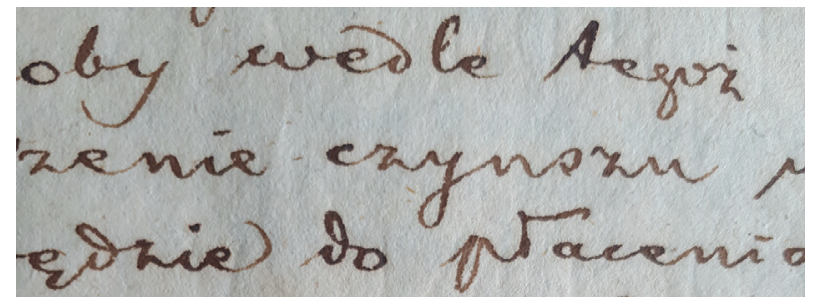

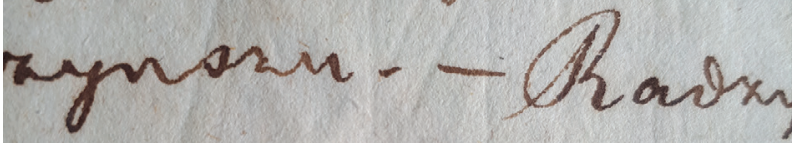

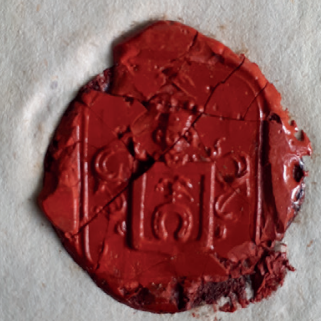



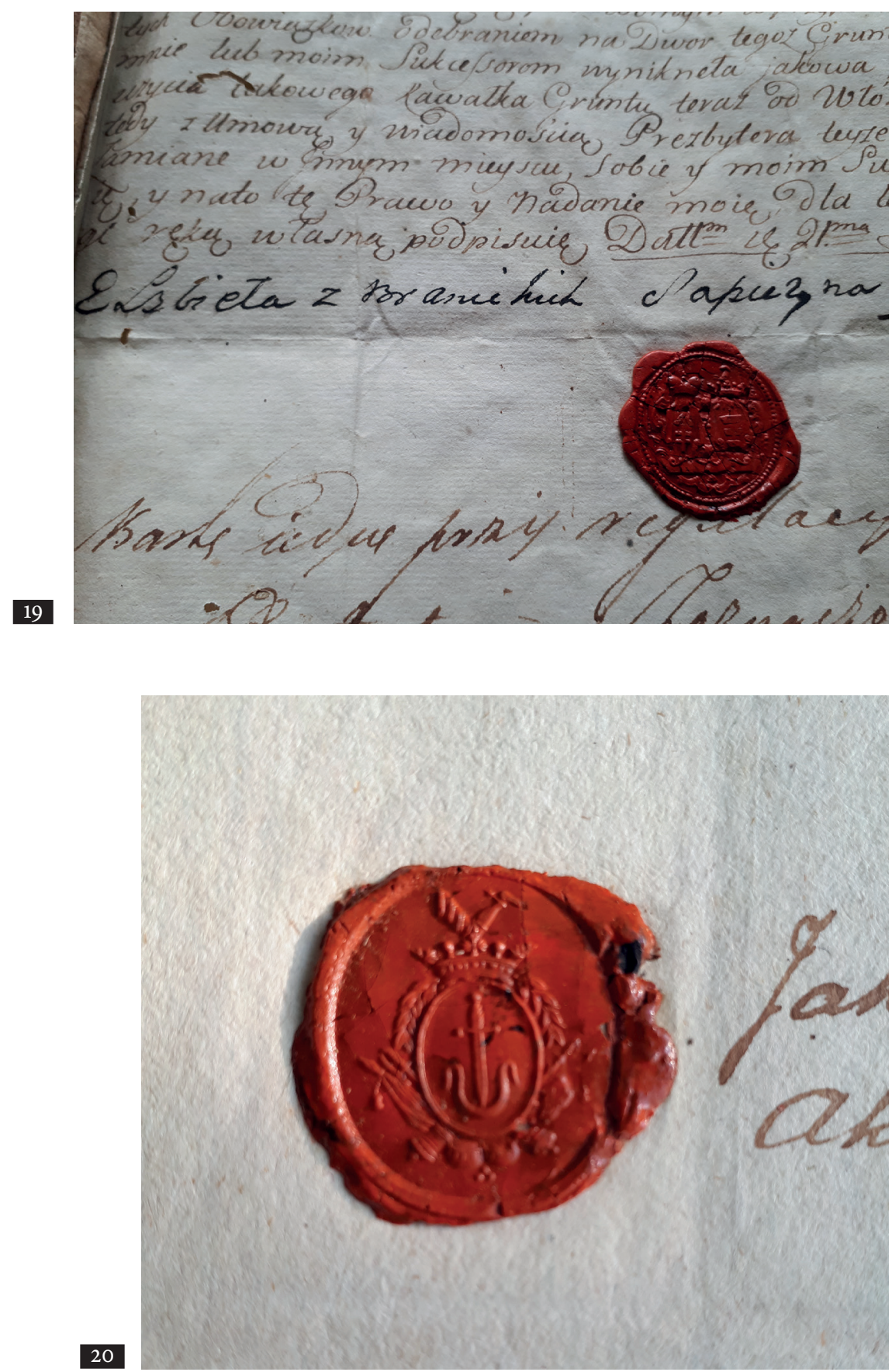
Joanna Kowalik-Bylicka

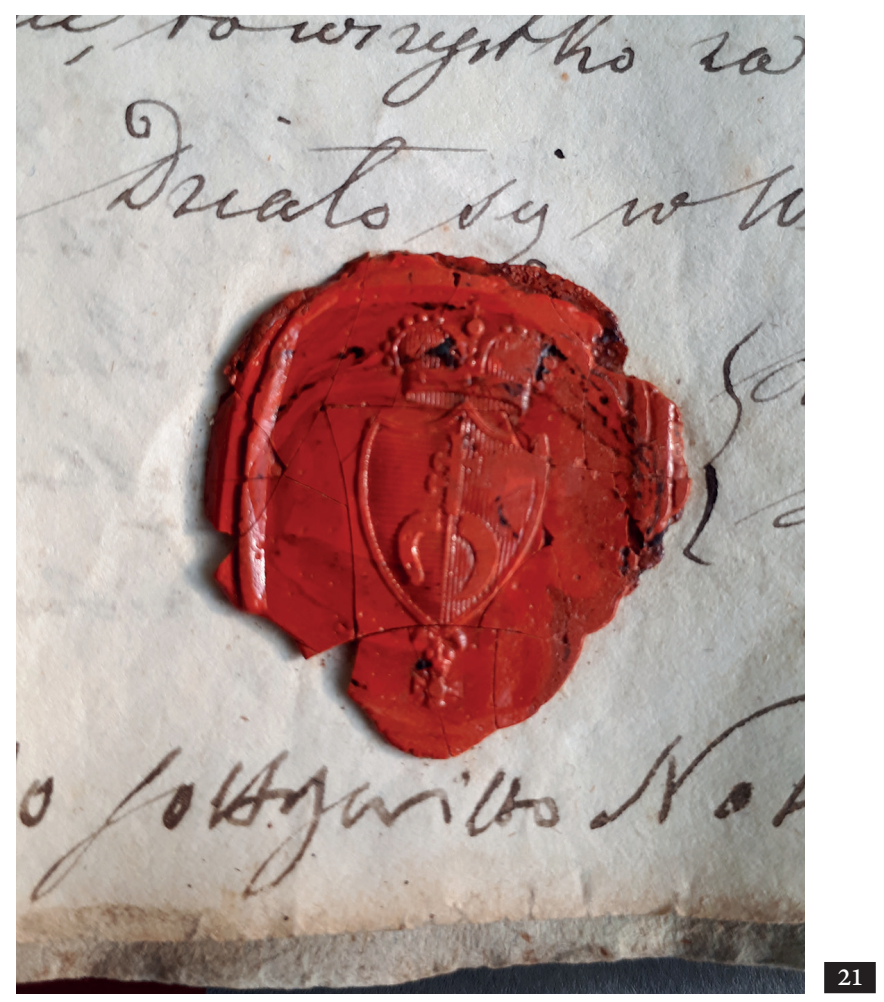



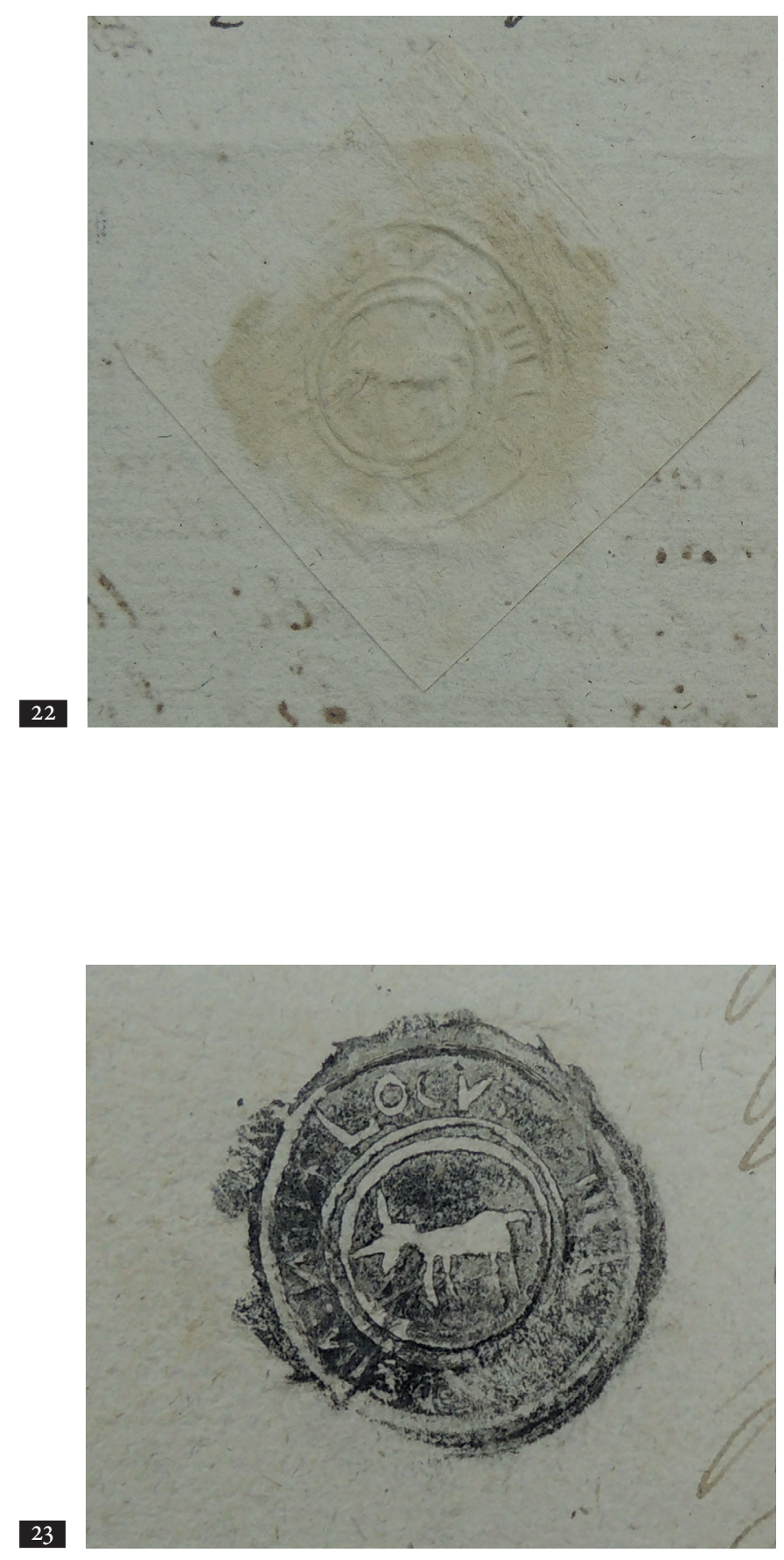